\title{
A first estimation of the contraction related to vertical axis rotation: the case of the Ibero-Armorican Arc formation
}

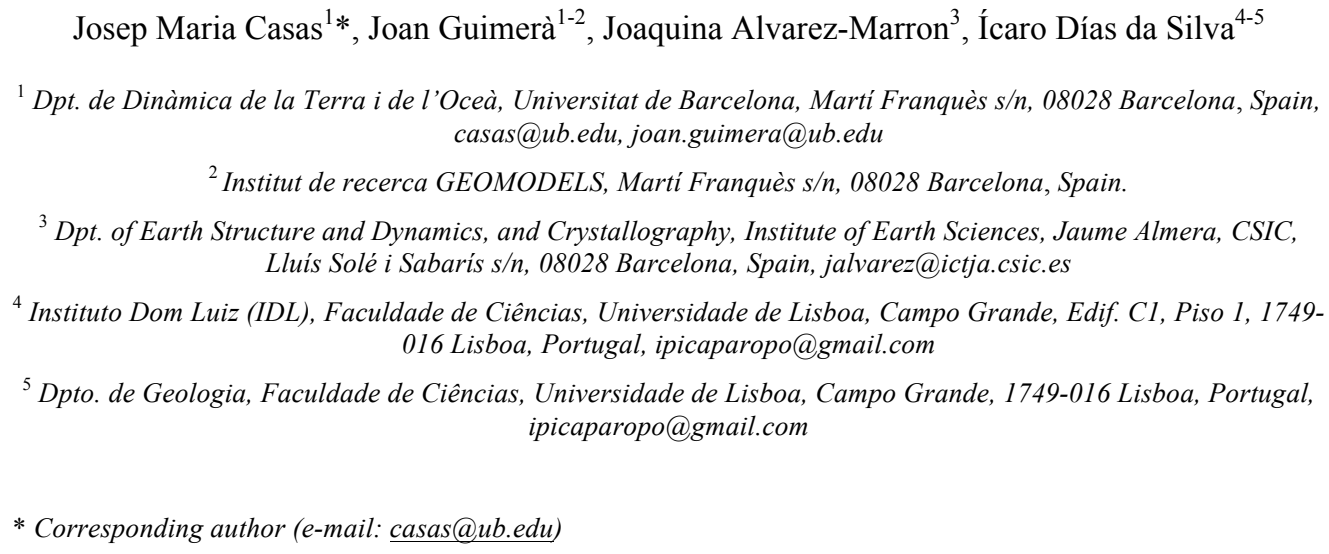

Abstract. Different models have been proposed to explain the formation of the Ibero-Armorican Arc, which require significant vertical axis rotations, at the end of the Variscan orogeny. Estimates of the amount of contraction (horizontal shortening) needed for these rotations range from $54 \%$ to $91 \%$ perpendicularly to the arc. These estimates are compared with coeval deformational structures developed in two areas of the orogen, one in the autochthonous hinterland underlying the Galicia-Trás-os-Montes Zone in the southern branch of the arc, and the other in the Cantabrian Zone foreland in the core of the arc. From this analysis it follows that the late Variscan deformation together with the subsequent Alpine contraction is not sufficient to explain the formation of the IberoArmorican Arc as a secondary structure by means of vertical axis rotations. Our analysis suggests this arc is mainly a primary, or non-rotational curve, slightly modified by ca. 10\% of superposed contraction during late Carboniferous and/or Alpine times. Moreover, we propose that the assumptions underlying the interpreted geometry of the arc be re-evaluated, and we discuss the role of late-Variscan regional strike-slip faults in the Iberian and in the Armorican massifs that probably acted consecutively before and during the contraction of the arc.

\section{Introduction}

Different models have been proposed to synthesize the structural evolution and explain the characteristic arcuate geometry of the western European Variscan Belt, known as the Ibero-Armorican Arc (IAA, Fig. 1). The indentor model requires a curved geometry of the Gondwanan margin prior to collision and highlights the role of the Gondwana promontory during the Gondwana-Laurussia collision (Matte and Ribeiro, 1975; Lefort, 1979; Brun and Burg, 1982; Burg et al., 1987; Quesada, 1991; Dias and Ribeiro, 1995; Sánchez-García et al., 2003; Simancas et al., 2009) (Fig. 2A). Other models propose that this arc constitutes an orocline formed by secondary vertical axis buckling of an originally oriented N-S belt during Gondwana-Laurussia collision (Weil et al., 2000, 2001, 2010, 2013a, 2013b, 2019; Gutiérrez-Alonso et al., 2012; Fernández-Lozano et al., 2016; Pastor-Galán et al., 2011, 2012b, 2015a, 2017, 2019; Shaw et al., 2012) (Fig. 2B). A third group of models emphasizes the role of the large-scale strike-slip shear zones and the associated deformation as the main origin for the formation of the Ibero-Armorican arc (Martínez-Catalán et al., 2007; Martínez-Catalán, 2011) (Fig. 2C). Although the oroclinal and indentor models 
may appear to be mutually exclusive, some authors reconcile both models in a proposal involving a combination of some indentation and subsequent sinistral and dextral motion along shear zones on either side of the promontory (Murphy et al., 2016) or subsequent buckling (Casas and Murphy, 2018) (Fig. 2D). One of the most critical points to discern between the different proposals is the amount of vertical axis rotation required. The secondary orocline models propose counter-clockwise vertical axis rotations ranging from $60^{\circ}$ or $70^{\circ}$ to $90^{\circ}$ for the southern arm of the Ibero-Armorican Arc and clockwise rotations of $25^{\circ}$ for the northern arm (Pastor-Galán et al., 2015a, b, 2016, 2017). In contrast, the amount of rotation required for some of the models involving indentation and subsequent buckling is ca. $27.5^{\circ}$ for both branches (Casas and Murphy, 2018). Although they clearly differ, these vertical axis rotations each require a significant amount of contraction and extension that has yet to be quantified but which should be recognizable in the surrounding regions. With the exception of the indentor model, the other models agree that the vertical axis rotations occurred in late Carboniferous-Early Permian times (ca. 305-295 Ma), after the main Variscan deformational events that include the emplacement of the regional allochthons. In this contribution, we estimate the amount of contraction required for the different vertical axis rotations proposed for the formation of the IberoArmorican Arc, and we compare the obtained data with deformational structures developed simultaneously. For this comparison, we focus in two areas in the southern branch of the arc: (i) the parautochthon of the Galicia-Trás-osMontes Zone and the underlying autochthonous hinterland of the Central Iberian Zone in the southern branch of the arc, and (ii) the Cantabrian Zone foreland in the core of the arc. Incorporation of these results into future reconstructions may test the validity of the proposed models, and constrain the geometry and the origin of the arc and the role of the large strike-slip faults.

In this contribution we follow the Marshak's (2004) terminology for curving fold-thrust belts which distinguishes between rotational and non-rotational curvatures depending on whether or not segments of the belt rotated around an imaginary vertical axis.

\section{Geological setting of the Iberian Massif}

The Iberian Massif includes several tectonically juxtaposed geological domains with important differences in their stratigraphic, structural, magmatic and metamorphic evolution (Lotze, 1945; Julivert et al., 1972; Farias et al., 1987) (Fig. 1). In SW Iberia, the South-Portuguese Zone (SPZ) is a tectonically imbricated Devonian to late Carboniferous stratigraphic sequence, facing towards the southwest, that consists of synorogenic marine sediments with abundant volcano-sedimentary components (Oliveira et al., 2019) with Laurusian affinity (Braid et al., 2011; Pérez Cáceres et a., 2017; Pereira et al., 2020). The Ossa Morena Zone (OMZ) represents the northern Gondwana margin (Quesada, 1991; Pereira et al., 2012), composed of Neoproterozoic, Cadomian-related, synorogenic sediments unconformably overlain by lower Cambrian to Lower Devonian passive-margin volcano-sedimentary sequences (Sánchez García et al., 2019; Gutierrez Marco et al., 2019), which are in turn unconformably overlain by Upper Devonian to early Carboniferous flysch basins (e.g. Camargo Rocha et al., 2009; Oliveira et al., 2019).

The boundary of the OMZ with the northern sector of the Iberian Massif is the Coimbra-Cordoba Shear Zone (e.g. Pereira et al., 2008) or the Badajoz-Cordoba Shear Zone (BCSZ) (Azor et al., 1994, 2019) (Fig. 1). The northern Iberian Massif can be divided in two major domains: i) The Allochthon, called Galicia-Tras-os-Montes Zone (GTMZ) includes several stacked sheets; ii) the Autochthon, comprising the Central Iberian (CIZ, hinterland), West Asturo-Leonese (WALZ) and the Cantabrian Zone (CZ, foreland) in the core of the Iberian-Armorican Arc (e.g. Lotze, 1945; Julivert et al., 1972; Farias et al., 1987; Gutierrez Marco et al., 1990; Pérez-Estaún et al., 1988, 1990). 
slices, the Upper Allochthon represents a terrane that was detached from the northern Gondwanan margin during the Lower Palaeozoic opening of the Rheic Ocean, accreted to southern Laurussia in the Silurian and in the Devonian during Variscan collision was thrust over the Iberian margin of Gondwana (e.g. Gómez Barreiro et al., 2007; Martínez Catalán et al., 2019). The Middle Allochthon is a rootless suture zone that preserves vestiges of the Rheic Ocean that was consumed by subduction beneath the southern Laurussian margin (e.g. Arenas and Sánchez Martínez, 2015). The Lower Allochthon represents a segment of the Gondwanan margin that was subducted and incorporated by obduction into the Variscan accretionary prism (e.g. Díez Fernández et al., 2011). The lowermost tectonic unit of the GTMZ, the Parautochthon (Dias da Silva et al., 2014a, 2015, 2020; González Clavijo et al., 2016) also called the Schistose Domain (Farias et al., 1987) or the Parautochthonous Thrust Complex (Ribeiro et al., 1990), can be divided into Upper Parautochthon, made up of a Cambrian-Silurian stratigraphic sequence comparable to the CIZ (Dias da Silva et al., 2014a, 2015, 2016); and the Lower Parautochthon comprised of synorogenic early Carboniferous marine strata imbricated in a piggy-back thrust sequence (Rodrigues et al., 2013; Dias da Silva et al., 2015; González Clavijo et al., 2016; Martínez Catalán et al., 2016).

The autochthon consists of Neoproterozoic to Lower Devonian stratigraphic sequences, within which are two major unconformities that record global Lower Palaeozoic extensional events related to the formation of a passive margin along the northern margin of Gondwana and the opening of the Rheic Ocean (Gutierrez Marco et al., 1990; Martínez Catalán et al., 1992; Dias da Silva et al., 2011; 2014b). The WALZ and CZ preserve more proximal facies than the CIZ (Marcos et al., 2004).

The deformation history of the Iberian Massif is complex, polyphase and diachronous. Devonian deformation (ca. 410-370 Ma) reflects subduction-related metamorphism followed by obduction, development of detachments and out-of-sequence thrusting recognized in the allochthonous complexes of the GTMZ (e.g. Gómez Barreiro et al., 2007; Martínez Catalán et al., 2009). This deformation is younger in the Lower Allochthon and older in the Upper Allochthon, and records the orogenic stacking and progradation of the orogenic front towards the Gondwana foreland.

In northern Iberia, the oldest Variscan deformation and metamorphic event started in the Upper Parautochthon and CIZ (365-355 Ma) and migrated into the WALZ and CZ by about 340-310 Ma (Dallmeyer et al. 1997). This $\mathrm{D}_{1}-\mathrm{M}_{1}$ stage was accompanied by the development of an $\mathrm{S}_{1}$ axial planar cleavage and by chlorite to biotite zone metamorphism that was synchronous with the development of a foreland basin fed by detritus derived from both the accretionary prism and the peripheral bulge in the autochthon (Dias da Silva et al., 2015). Around $340 \mathrm{Ma}$ (Dallmeyer et al., 1997), the Upper Parautochthon was tectonically imbricated at the base of the unrooted allochthonous complexes (Martínez Catalán et al., 2009) and both were tectonically transported towards present-day southeast (Dias da Silva, 2014; Dias da Silva et al., 2020). The Upper Parautochthon was thrust onto its foreland basin (Lower Parautochthon) (Dias da Silva et al., 2014a, 2015). This stage ( $C_{2}$ after Martínez Catalán et al., 2014) was responsible for the underthrusting of the underlying autochthon, leading to the regional Barrovian metamorphism peak $\left(\mathrm{M}_{1}\right)$. The emplacement of the GTMZ deformed the precursor $\mathrm{D}_{1}$ folds $\left(\mathrm{C}_{1}\right.$ after Martínez Catalán et al., 2014), and caused the folding of rocks in both Parautochthon and the underlying autochthon around the basal thrust-zones of the GTMZ (Ribeiro, 1974; Dias da Silva, 2014; Pastor-Galán et al., 2019; Dias da Silva et al., 2020) thus forming the Central Iberian Arc according to Martínez Catalán et al. (2014) and Dias da Silva et al. (2020).

Tectonic stacking of the GTMZ triggered synorogenic extension and adiabatic decompression $\left(\mathrm{D}_{2}-\mathrm{M}_{2}\right)\left(\mathrm{E}_{1}\right.$ in Martínez Catalán et al., 2014 and Alcock et al., 2015). The $\mathrm{D}_{2}-\mathrm{M}_{2}$ event (340-320 Ma) is characterized by the formation of extensional gneiss domes with orogen-parallel transport of the hanging-wall lithologies towards the 
southeast (modern coordinates) (Escuder et al., 1994; Arenas and Martínez Catalán, 2013; Díez Fernández and Pereira, 2016; Rubio Pascual et al., 2016). The gneiss domes developed in northern Iberia beneath the GTMZ, are rooted in the autochthon (Díez Fernández et al., 2017). The $\mathrm{D}_{2}-\mathrm{M}_{2}$ event progressed towards more continental realms, affecting the WALZ at about 320-310 Ma (Martínez Catalán et al., 2003). Synchronously, the orogenic front migrated further into Gondwana, with the development of the foreland thrust belt in the CZ (Pérez-Estaún et al., 1988).

The late Variscan (ca. 315-300 Ma) in Iberia is marked by heterogeneous upright folding and transcurrent brittleductile shear zones, under low-grade metamorphic conditions $\left(\mathrm{D}_{3}-\mathrm{M}_{3}\right)$ (Gonzalez Clavijo et al., 1993; GutierrezAlonso et al., 2015; Díez Fernández and Pereira, 2016, 2017; Dias da Silva et al., 2018). The $\mathrm{D}_{3}-\mathrm{M}_{3}$ folds folds, cogenetic stretching lineations and axial planar cleavages, are parallel to the orogenic trend and with the $\mathrm{D}_{1}-\mathrm{M}_{1}$ folds (Pastor-Galán et al., 2019). At the end of the $\mathrm{D}_{3}$, deformation became focused into a network of brittle-ductile shear zones, affecting especially the margins of $\mathrm{D}_{2}-\mathrm{M}_{2}$ gneiss dome cores and pre- to late- $\mathrm{D}_{3}$ granitic intrusions (Fig. 1). Conjugate dextral and sinistral shear zones locally steepened the previous fabrics, causing localized retrograde metamorphism, and shuffled the different tectono-metamorphic domains, juxtaposing low grade and high grade metamorphic rocks (e.g. Díez Fernández and Pereira, 2016; Dias da Silva et al., 2020). During this stage (307-300 Ma) the Porto-Tomar Shear Zone (PTSZ, Fig. 1) formed (Gutiérrez-Alonso et al., 2015) as a major dextral strikeslip shear zone that, according to some authors, connects with the dextral Armorican shear zones in the Armorican Massif (Martínez-Catalán et al., 2007; Martínez-Catalán, 2011, 2012) (Fig. 1).

\section{Proposed models for the arc formation}

The models that propose a secondary origin for the Ibero-Armorican Arc (IAA) agree that it formed at the end of the $\mathrm{D}_{3}$ deformational event (305-295 Ma, Kasimovian-Asselian) (Weil, 2006; Weil et al., 2010; Martínez-Catalán, 2012) and in a geometry that resembles a vertically-plunging fold. However, they assign different mechanisms to its formation (Fig. 2B and C). A group of models argue that the arc formed as a result of a lithospheric-scale buckling of an initial N-S oriented linear orogen (Weil et al., 2000, 2001, 2010, 2013a, 2013b, 2019; Gutiérrez-Alonso et al., 2004, 2012; Fernández-Lozano et al., 2016; Pastor-Galán et al., 2011, 2012b, 2015a, 2017, 2019; Shaw et al., 2012). This buckling caused a rotation of ca. $90^{\circ}$ of both arms of the arc, giving rise to a vertical fold with a tight geometry (Fig. 2B). This model implies a $90^{\circ}$ change in the contraction direction (from E-W to N-S) during the Variscan deformation. The model has other geodynamic implications, such as the development of an important magmatic event related to delamination of the thickened lithospheric root at the core of the arc (Gutiérrez-Alonso et al., 2011). Structures accounting for the deformation related to these important vertical axis rotations have been described only in the Cantabrian Zone, in the core of the arc, where the development of a system of radial folds simultaneously with the arc formation, together with the reactivation of existing thrust sheets (Esla Unit) and the southward thrusting of the Picos de Europa Unit have been proposed (Weil et al., 2000, 2001, 2013a, 2013b; Pastor-Galán et al., 2012a; Merino-Tomé et al., 2009).

Martínez-Catalán et al. (2007) and Martínez-Catalán (2011) have suggested that the arc formed as a result of symmetrical $90^{\circ}$ rotation of existing tectonostratigraphic zones due to continental-scale dextral shear faulting originated by an oblique collision. As with the previous model, this rotation resulted in an arc with tight geometry (Fig. 2C). In this model, the Porto Tomar shear zone (Ribeiro et al., 1980) merges into the South Armorican shear zone (Shelley and Bossière, 2002; Martínez-Catalán et al., 2007) in the Armorican Massif. These faults were initially quasi-linear and significant changes in their orientation (NE-SW in the western margin of the Iberian 
161 Massif, E-W in northwest Galicia and WNW-ESE in the Armorican Massif) were caused by folding during the 162 formation of the Ibero-Armorican Arc. According to Martínez-Catalán (2011) the motion of these dextral shear zones during Gondwana-Laurussia convergence explains the stratigraphic similarity between the Central Armorican and the Central Iberian zones and may account for the original proximity of Crozon (western Armorican Massif) and Buçaco (western Portugal) (Fig. 1) which exhibit similar Ordovician stratigraphic successions (Young, 1988, 1990; Robardet, 2002 and references therein). This proposal implies a southern original position for the Armorican Massif either to the south or in front or of the western edge of the Iberian Massif during the Ordovician, before the development of the IAA (Young, 1990; Robardet, 2002). A southernmost position for the Armorican Massif during the Ordovician has also been proposed to explain the distribution of the Late Ordovician (Katian) Nicolella Community brachiopod populations by Colmenar (2015). Other group of models invoke a combination of indentation and subsequent dextral and sinistral motion along shear zones on either side of the promontory (Murphy et al., 2016) or subsequent buckling (Casas and Murphy, 2018). Murphy et al. (2016) propose that the continental edge can have a promontory, even if the geological belts are approximately-linear and the model of Casas and Murphy (2018) is based on palinspastic restoration and preorogenic geological constraints and proposes a Gondwanan margin with an irregular pre-Variscan geometry, with two E-W oriented segments linking a N-S central segment. This Gondwanan promontory was cut and offset by regional strike-slip faults, and each segment was rotated ca. $27.5^{\circ}$ about a vertical axis during late Variscan arc formation (Fig. 2D). This amount of rotation has been deduced from the geometry of the South Armorican and Porto-Tomar shear zones, assuming that they initially constituted the same fault system with a linear geometry (Fig. 180 2D).

181 Some authors propose the existence of a second arc in the Iberian Massif, with opposite curvature to the IAA, the Central Iberian Arc (CIA) (Fig. 1). However, there is great controversy about its age of formation or even its actual existence. According to Martínez-Catalán et al. (2014) and Dias da Silva et al. (2020), the CIA was a consequence of the tectonic imbrication of the GTMZ onto the Iberian autochthon. This imbrication would have caused the rotation of the previous structures and stratigraphy, that was tightened during the $\mathrm{D}_{3}$ stage, synchronously with the formation of the IAA. In contrast, Shaw et al. (2012, 2014), Gutierrez-Alonso et al. (2015) and Weil et al. (2019) have proposed that the formation of IAA and CIA arcs was contemporaneous, due to oroclinal bending of a former linear orogen with a N-S trend, taking place at the end of the Variscan orogeny. However, Pastor-Galán et al. (2015a, 2016, 2017, 2019) have argued that the CIA is an inherited feature that supports the pre-Variscan irregular geometry of the Gondwanan margin proposed by Casas and Murphy (2018). Pastor-Galán et al. (2015a) proposed that it had to have formed prior to the development of the IAA, even if the CIA were a secondary arc. Dias da Silva et al. (2020) added that the secondary origin of the CIA is related to the thin skinned emplacement of a lateral extrusion wedge formed by the collapse of the Variscan accretionary prism in the French Massif Central at approximately 360-340 Ma.

\section{The amount of contraction required by the different proposed models}

196 A simplified way to estimate the amount of contraction required to cause rotation along the vertical axis of the 197 branches of the arc is presented in Figure 3. We estimate the amount of contraction related to the different vertical 198 axis rotations, which has been proposed for the southern branch of the IAA, by comparing the initial length of a 199 segment of the arc versus the final width that separates the tip of the two branches of the arc defined by the same 200 segment (Fig. 3). In doing so, we obtain the percentage of contraction between the two arms of the arc. The 
contraction estimate obtained depends on the original length of the previously linear orogen and on the final shape (more or less tight) of the arc. Moreover, we can estimate the amount of "lost" lithosphere by comparing the initial trace of the WALZ-CZ boundary versus its final trace (Figs. 4 and 5).

The oroclinal bending about a vertical axis of a linear orogen (Weil et al., 2000, 2001, 2010, 2013a, 2013b, 2019; Gutiérrez-Alonso et al., 2012; Fernández-Lozano et al., 2016; Pastor-Galán et al., 2011, 2012b, 2015a, 2017, 2019; Shaw et al., 2012) implies a rotation of ca. $90^{\circ}$ for both branches of the arc to obtain its tight geometry (Fig. 4A). After this rotation, a fragment of the linear orogen of at least $1475 \mathrm{~km}$ length, exhibits a final length that is equivalent to the width of the vertical fold, that is $127 \mathrm{~km}$. This implies a contraction of about $91 \%$ at the tip of the inner part of the generated arc (Fig. 4A), and an amount of lost lithosphere around $69810^{3} \mathrm{~km}^{2}$ (Fig, 5A).

A similar result was obtained in the model of the secondary fold forming as a result of strike-slip faulting (MartínezCatalán et al., 2007; Martínez-Catalán, 2011). In this case, considering an initial length of ca. $1550 \mathrm{~km}$ and a final width measured across the fold about $95 \mathrm{~km}$, the amount of required contraction is about $94 \%$ and the surface of lost lithosphere is around $76710^{3} \mathrm{~km}^{2}$ (Fig. 5B). Moreover, this model implies an important phase of extension in the hinterland situated north of the arc. We estimate the amount of extension required to be ca. $100 \%$ (680 to $1370 \mathrm{~km}$, Fig. 4B), however features associated with it have not been identified.

The model proposed by Casas and Murphy (2018) requires a rotation of $27.5^{\circ}$ for both branches, similar to the ca. $25^{\circ}$ clockwise rotation proposed for the northern arm of the arc by Pastor-Galán et al. (2015b). If we apply the same method to the geometry proposed by Casas and Murphy (2018), the amount of contraction is considerable, ca. 54\%, and the reduction in the surface of lithosphere, although less than in the previous models, is also significant, around $3610^{3} \mathrm{~km}^{2}$ (Fig. 5C). All the previous figures on the amount of lost lithospheric surface should be considered as minimum values, as the calculations of Fig 5 assumed no change in the position of the orocline hinge during its development.

\section{The geological data}

To compare these estimated amounts of contraction with actual structures developed in late Variscan times, we focussed our analysis in the autochthon of the CIZ, just beneath the parautochthon of the GTMZ, where $\mathrm{D}_{3}$ structures are well developed (Dias da Silva, 2014), and in the Cantabrian Zone, the core of the arc, where a development of radial folds (Julivert and Marcos, 1973; Weil et al., 2000, 2001, 2012, 2013; Pastor-Galán et al., 2012a), the reactivation of previous thrusts (Weil et al., 2013) and the emplacement of the youngest thrust units, the Cuera Unit and the Picos de Europa Province (Merino-Tomé et al., 2009) coeval with the arc formation have been proposed.

\subsection{The Parautochthon of the GTMZ and the autochthon (CIZ) beneath}

In NW Iberia, $\mathrm{D}_{3}$ structures affect the GTMZ (including the Parautochthon) and the tectonically underlying CIZ (Fig. 6A). These $\mathrm{D}_{3}$ structures overprint all the previous structures, including the $\mathrm{D}_{1}$ folds that wrap around the GTMZ, the main basal thrusts and detachments that limit the allochthonous domains as well as the $\mathrm{D}_{2}$ extensional detachments and $\mathrm{M}_{2}$ isograds that bound the gneiss dome (Azor et al., 2019; Dias da Silva et al. 2020).

There are two types of $\mathrm{D}_{3}$ structures: i) fan-like heterogeneous folds whose style adapted to the previous structures, creating a strain shadow with convergent folds to the east and beneath the GTMZ, which acted as a rigid body (Alonso and Rodríguez, 1981; Dias da Silva, 2014); and ii) conjugate dextral and sinistral transcurrent brittle-ductile shear zones (e.g. González Clavijo et al., 1993; López-Plaza and López-Moro, 2004; Gutierrez Alonso et al., 2015). 
The shear zones predominantly affect the pre- to syn- $\mathrm{D}_{3}$ granites and the $\mathrm{D}_{2}$ gneiss dome cores in both the CIZ and GTMZ (Escuder et al., 1994; Alcock et al., 2015; Díez Fernández et al., 2017; Dias da Silva et al., 2020). In the eastern rim of GTMZ (i.e. the southern limb of the IAA), the $\mathrm{D}_{3}$ folds range in orientation from oblique to orthogonal relative to the $D_{1}$ structures. The interference of $D_{3}$ folds with $D_{1}$ and $D_{2}$ folds formed type 1 and type 2 fold interference patterns of Ramsay and Huber (1987) (see Pastor-Galán et al., 2019; Dias da Silva et al., 2020). As a consequence, the $\mathrm{D}_{3}$ folds have variable plunges, from vertical to sub horizontal, with WNW and to ESE sense of plunge and a regular WNW-ESE axial plane. $\mathrm{D}_{3}$ folds exhibit sub-vertical axial surfaces. The axial planar crenulation cleavage $\left(\mathrm{S}_{3}\right)$ shows near vertical fan-like dispersion that is more evident where a previous subhorizontal layering is present. The folding is highly heterogeneous at all scales, with sectors where there are tight isoclinal folds separated by areas with more open folds (Dias da Silva et al., 2020).

Retrograde metamorphism and the reworking of the previous fabrics occur adjacent to brittle-ductile transcurrent conjugate shear zones. These shear zones also produce proto-mylonitic to ultra-mylonitic fabrics associated with faults, with intrafolial and sheath folds, C- and C'-S pairs, quarter structures, tectonic fish and sigmoidal shapes in porphyroclasts and syn-tectonic porphyroblasts (as in the aureoles of the syn- to late- $\mathrm{D}_{3}$ granites) (Dias da Silva et al., 2020). However, in upper structural levels, these features are less common. Instead, a well developed crenulation cleavage is associated with tight isoclinal folds. Taken together, it appears that $\mathrm{D}_{3}$ flattening was accommodated by motion along conjugate transcurrent shear zones in the high grade metamorphic domains (gneiss domes, granites, etc.) and by folding in the low grade metamorphic domains (Dias da Silva et al., 2020).

The $\mathrm{D}_{3}$ folds and shear zones enclose pre-to syn- $\mathrm{D}_{3}$ granitic bodies, which acted as rigid bodies. The $\mathrm{D}_{3}$ structures steepened some pre-existing structures, such as the thrusts and detachments of the GTMZ and the $\mathrm{D}_{2}-\mathrm{M}_{2}$ fabrics and isograds of the gneiss domes (e.g. Díez-Fernández and Pereira, 2016, 2017; Dias da Silva et al., 2020). The regional orientation of $\mathrm{D}_{3}$ structures changes from N-S in the western limb of the IAA to WNW-ESE in the southern limb of the IAA (Martínez Catalán et al., 2014).

The value of contraction caused by the $\mathrm{D}_{3}$ structures in the CIZ was estimated from a cross-section (Fig. $6 \mathrm{~B}$ ). The base of the Armorican Quartzite was chosen to calculate the contraction in two sectors not affected by granite intrusions (Fig. 6C). Adding both sectors and comparing their initial and final lengths, the elongation obtained was equal to -0.05 , implying a contraction (horizontal shortening) of $5 \%$. However, the additional contraction produced by the conjugate, upright, transcurrent brittle-ductile shear zones should be included, although clear markers cannot be identified to get an estimation, and no significant displacement of the granitic batholiths is depicted in Fig. 6B.

\subsection{The Cantabrian Zone}

The Cantabrian Zone (CZ) is the external thrust-and-fold belt of the Variscan orogen that developed by thin-skinned deformation at the end of the Carboniferous (Julivert, 1971; Marcos and Pulgar, 1982; Perez-Estaún et al., 1988). The thrust-and-fold belt deforms pre-orogenic and syn-orogenic Paleozoic sedimentary successions. The youngest strata of the pre-orogenic succession are Lower Carboniferous in age and form a sedimentary wedge thinning towards the foreland. The syn-orogenic succession includes late Carboniferous strata and occurs as several clastic wedges that were deposited in foredeeps coeval with the major thrust events (Marcos and Pulgar, 1982). The $\mathrm{CZ}$ includes a set of arcuate thrust units that were emplaced from west to east in present coordinates. The oldest thrusts are in the SW and are Bashkirian (Westphalian A) in age (Arboleya, 1981; Marcos and Pulgar, 1982), 
geometry of corresponding thrusts (i.e. Bastida et. al., 1984: Alonso, 1987; Pérez-Estaún et al., 1988; AlvarezMarron, 1995; Bulnes and Aller, 2002; among others) (Fig. 7, 8). The major folds in the CZ have been classified into two sets based on the distribution of axial traces in map view with respect to the trend of major thrusts that impart the arcuate shape to the CZ (Julivert and Marcos, 1973). Folds with axial traces trending sub-parallel to the trace of the thrusts, mostly developed within individual thrust-sheets, have been classified as longitudinal folds, whereas folds with axial traces trending sub-perpendicular to the thrusts that extend across several major thrust units have been classified as radial folds.

More recent studies have shown that lateral structures in the form of ramps and folds and tear faults are common These lateral structures may have developed in individual thrust sheets or may reflect the complex evolution and superposition during emplacement of the thrust pile. The large tectonic superposition of some of the thrust units also caused accommodation structures in the form of lateral culminations and drop faults on a previously emplaced thrust sheet above an active underlying sheet. In the CZ, a change in the direction of tectonic transport is particularly evident between the emplacement of the Picos de Europa and Ponga Units. The former shows transport towards the NE and E (Alvarez-Marrón, 1995) whereas the latter shows transport towards the S and SSW (Marquínez, 1989). Most individual thrust-related folds were modified during progressive thrusting and almost every major fold had a distinctive evolution during the development of the Cantabrian Zone thrust systems. As a result, most folds originally classified as longitudinal folds are now considered as frontal thrust-related folds (Alonso, 1987, PerezEstaún et al., 1988) (Fig. 8) and some folds classified as radial folds are now considered as lateral thrust-related folds (Alonso, 1987; Bastida and Castro, 1988; Alvarez-Marron, 1995). The Ponga Unit provides a good example of the variety in distribution, dimensions and attitude of thrust-related folds in the CZ (Fig. 7). The Ponga Unit lies in the core of the $\mathrm{CZ}$ and shows a complex fold interference pattern that was mainly caused by the superposition of thrust units with different emplacement directions. The emplacement direction was northeastward in rear thrust sheets but eastward in the frontal thrusts. Most lateral folds with E-W orientation were tightened during the subsequent south-directed emplacement of the Picos de Europa Unit (Alvarez-Marron, 1995).

The timing of formation of thrust-related folds in the CZ, spans the whole time of development of the Cantabrian Thrust Systems. The emplacement of earliest thrust units (Somiedo-Correcilla and Esla Units; Arboleya, 1981) occurred in the late Bashkirian ( $318 \mathrm{Ma})$. The south to south-southwest emplacement of the frontal unit in the internal part of the arc (Picos de Europa Province) occurred during the Kasimovan-Ghezelian transition ( $304 \mathrm{Ma})$ (Merino-Tomé et al., 2009). According to these authors the emplacement of the Picos de Europa Province caused contraction of $150 \pm 15 \mathrm{~km}$ that was distributed between southward displacement of the Cuera-Picos de Europa imbricate thrust system, reactivation of previous thrusts and out-of-sequence thrusting, and by internal deformation. Part of this contraction also may account for the tightening of the previously formed E-W oriented lateral folds in the Ponga Unit (Alvarez-Marron, 1995).

Further evidence for the age of formation of longitudinal and radial folds in the $\mathrm{CZ}$ is provided by structures associated with a Late-Variscan extensional episode and metamorphism (Valin et al, 2016). This episode includes the development of a cleavage that crosscuts longitudinal and radial folds and the frontal thrust of the Picos de Europa Unit (Aller et al., 1987; Aller et al., 2005; Valin et al., 2016). This cleavage is associated with very low to low grade metamorphism (Bastida et al., 1999; García-Lopez et al, 2018), and is overprinted by contact metamorphic aureoles related to granodiorites emplacement at 292 + 2/- 3 Ma (Valverde-Vaquero et al., 1999). 


\subsection{The geometry of the IAA}

Most models for the IAA agree that the arc has a very tight geometry (Fig. 1). This interpretation assumes: 1) the correlation of stratigraphy of the northern limb of the arc across the Bay of Biscay, and 2) eastward continuation of the northern arm of the arc across NE Iberia. However, both assumptions are problematic.

1) The correlation across the northern arm across the Bay of Biscay is speculative due to poor exposure, and thus strongly depends on the location attributed to the Iberian Plate in Late Permian-Early Jurassic times. However the Mesozoic evolution of the Iberian Plate is controversial. Different interpretations of the Mesozoic Atlantic and Bay of Biscay magnetic anomalies, especially magnetic anomalies older than M0 chron (ca. $125 \mathrm{Ma}$ ), have yielded several end-member models for the reconstruction of the Iberian Plate motion with different initial positions (see Barnett-Moore et al. 2016 and Muñoz 2019 for a detailed discussion) (Fig. 9). This is a critical uncertainty as the position and orientation of the Iberian Plate at the end of the Variscan orogeny strongly constrains the geometry of the Ibero-Armorican Arc. Until the extent of rotation due to Alpine orogenesis is understood, the problem of lateral correlation involving the megastructures on both sides of the Bay of Biscay renders any reconstruction of the IberoArmorican Arc highly speculative.

2) The geometry of the southwestern arm of the Ibero-Armorican Arc is tightly constrained by correlations of the Cambrian-Ordovician sequences within WALZ and Ollo de Sapo magmatic rocks within the CIZ (Montero et al., 2007; Montero el al., 2009, among others), both of which can be traced for hundreds of kilometres along strike (Martínez-Catalán et al., 2007). However, the geometry of the eastern arm of the arc is not so well constrained. This eastern branch would include the Basque massif or sub-domain (western Pyrenees) and the south-westernmost inlier of the Coastal Catalonian Ranges (Priorat massif), which are thought to represent the lateral continuation of the West Asturian-Leonese Zone (Martínez-Catalán et al., 2007) (Fig. 1). In the same way, the remainder of the Pyrenees is thought to be equivalent to the CIZ (Martínez-Catalán et al., 2007) (Fig. 1). However, as widely documented, the Cambrian-Ordovician geodynamic, stratigraphic and zircon provenance evolution of the eastern Pyrenees fits better with other neighbouring areas, such as the Montagne Noire and southern Sardinia, than with the rest of the Iberian Massif (see discussion in Álvaro et al., 2018; Casas et al., 2019). As a result, the northern and eastern prolongations of the Ibero-Armorican Arc are not well defined, compromising interpretations of the proposed tight geometry of the arc.

\subsection{The origin of the arc}

The analysis of the $\mathrm{D}_{3}$ structures affecting the autochthon of the GTMZ provided shortening values of about $5-10 \%$ (Fig. 6). This value is far less than the estimated $91 \%-94 \%$ of contraction required to form IAA as a secondary orocline, as proposed in the oroclinal and strike-slip models (Weil et al., 2000, 2001, 2010, 2013a, 2013b, 2019; Gutiérrez-Alonso et al., 2012; Fernández-Lozano et al., 2016; Pastor-Galán et al., 2011, 2012b, 2015a, 2017, 2019; Shaw et al., 2012; Martínez-Catalán et al. 2007; Martínez-Catalán, 2011). It is also significantly less than the 54\% contraction implied in the model involving indentation and subsequent buckling (Casas and Murphy 2018). In the $\mathrm{CZ}$ core of the arc, the horizontal contraction of $150 \pm 15 \mathrm{~km}$ related to the emplacement of Picos de Europa Unit (Merino-Tomé et al., 2009) must be re-evaluated. Using the control points proposed by these authors (Fig. 11, Merino-Tomé et al., 2009), the contraction related to the emplacement of the imbricate thrust system is around 58 $\mathrm{km}$. These $58 \mathrm{~km}$ represent only one third of the approximate contraction of $164 \mathrm{~km}$ experienced by this segment of the Cantabrian Zone if it developed as a result of the bending around a vertical axis of a linear orogen (see insert in Fig. 4A). In addition, the age of emplacement of these youngest thrust units in the Cantabrian zone towards the 
south is documented to have been ongoing from 304 to 299 Ma (Valin et al., 2016; Merino-Tomé et al., 2009), coetaneous with the sedimentation of the molasses, Kasimovian to Gzhelian in age (Merino-Tomé et al., 2009, 2019-Fig. 11.5). In turn, these molasses unconformably overlie NW-SE and W-E-oriented thrusts and folds in the southern Cantabrian Zone (e.g. in the Villablino coalfield, which cross-cuts the WALZ-CZ boundary (IGME, 1982), and the La Magdalena coalfield (IGME, 1984). That is, these strata postdate not only the emplacement of the major tectonic units in the $\mathrm{CZ}$ but also the arc formation, which must be older than the emplacement of the Picos de Europa Unit. Moreover, the CIZ-WALZ boundary should had experienced a contraction of $109 \mathrm{~km}(32 \%)$, in a N-S direction, during the closure of the arc (see insert in Fig. 4A), whereas no structures attributable to this have been reported inside the WALZ.

Additionally, we propose that N-S contraction during the development of the Alpine deformation along the northern Iberian margin may also have contributed to some tightening of the arc. In the southern border of the CZ, Marín et al. (1995) estimated $20 \mathrm{~km}$ of contraction in Domo de Valsurvio and Curavacas syncline during the Alpine deformation. Pulgar et al. (1999) have proposed a similar South displacement of ca. $22 \mathrm{~km}$ for the entire CZ. This moderate Alpine overprinting of Variscan features is similar to that described in other areas of the Iberian Massif. For example, Alpine thrusts caused displacements ranging between 25 to $30 \mathrm{~km}$ in the Iberian Range (Casas-Sáinz, 1993; Guimerà et al., 1995), and ca. 25 km in the Central System (Warburton and Álvarez, 1989). An Alpine contraction of $40 \mathrm{~km}$ to $60 \mathrm{~km}$ in a NNE-SSW direction has been estimated for the whole Iberian Range (Guimerà et al., 1995, 2004; Guimerà, 2018). The superposition of Alpine over Variscan folds has also been proposed in the Carboniferous rocks of the Priorat area in the Catalan Coastal Range (Valenzuela et al., 2016).

Even considering late Variscan deformation in combination with Alpine deformation there is not enough contraction to explain the formation of the arc as a secondary structure. The results of our analysis suggest the Ibero-Armorican Arc is mainly a primary or non-rotational curvature, slightly modified during late Carboniferous and Alpine times. This model implies that the relationship between the Central Iberian Arc and the Ibero-Armorican Arc, considered both as margin-controlled curves, remains an open question.

\subsection{The role of the large strike-slip faults}

In the models involving strike-slip faulting deformation and oblique collision (Martínez-Catalán et al., 2007; Martínez-Catalán, 2011) or indentation and subsequent buckling (Casas and Murphy, 2018), the large late-Variscan dextral strike-slip faults play an important role (Fig. 2C and D). In both cases it has been assumed that the Porto Tomar shear zone merges in the Armorican Massif with the South Armorican shear zones (Fig. 1) and that these shear zones were initially linear. It is also assumed that they constitute the southern margin of the French Massif Central. Using Crozon (Brittany) and Buçaco (Portugal) areas as piercing points, Casas and Murphy (2018) estimated a total dextral offset of around $900 \mathrm{~km}$ between the Iberian and Armorican massifs during the late Moscovian-Kasimovian along the Porto Tomar-South Armorican shear zone system, before its folding during the arc deformation. However, if a primary origin for the arc is assumed, another relationship between these strike-slip faults must be envisaged, as the South Armorican and the Porto Tomar shear zone system would not represent the same megastructure before the arc formation. An alternative explanation is to consider that they constitute two separate faults that acted consecutively. First, a dextral displacement along the NE-SW Porto Tomar shear zone of about $450 \mathrm{~km}$, and then offset of this structure by the dextral movement of the South Armorican shear zone system oriented WNW-ESE. In this case, the northern prolongation of the Porto Tomar shear zone may be located somewhere in the Northern Armorican Domain. The restoration of this strike-slip faults consecutive movement 
400 results in a pre-tectonic arrangement of the different tectono-stratigraphic units compatible with the paleogeographic reconstruction proposed by Casas and Murphy (2018).

\section{Conclusions}

From the analysis proposed here, it follows that late Variscan deformation together with the Alpine deformation is not sufficient to explain the formation of Ibero-Armorican Arc as a secondary structure by means of vertical axis rotations. We propose that this arc is mainly a primary, or non-rotational curve, slightly modified by ca. $10 \%$ of superposed contraction during late Carboniferous and/or Alpine times.

Therefore, this amount of deduced contraction cannot account for the tight curvature of the Ibero-Armorican Arc if originated as a linear orogenic feature. Moreover, the North side of this curvature is not supported by regional geological data. We consider it necessary to re-evaluate the geometry of the arc, after considering how Alpine movements affected the post-Variscan position of the Iberian Plate.

Another relationship between the late-Variscan large strike-slip faults in the Iberian and in the Armorican massifs must be envisaged. Probably the Porto Tomar and the South Armorican shear zone systems do not represent the same megastructure on both sides of the Bay of Biscay. Instead, these structures may have acted consecutively.

\section{Acknowledgements}

We acknowledge the financial support provided by CGL2017-87631-P, CGL2016-76438-P, PGC2018-093903-BC22 and SALTCONBELT-CGL2017- 85532-P projects, funded by Agencia Estatal de Investigación (AEI) and Fondo Europeo de Desarrollo Regional (FEDER); and by project 2014SGR-467 (GEOMODELS Research Institute and the Grup de Geodinàmica i Anàlisi de Conques). IDS thanks the financial support given by the "Estímulo ao Emprego Científico - Norma Transitória" national science contract in the Faculdade de Ciências da Universidade de Lisboa. This work is a contribution to the IGCP project 648, the IDL's Research Group 3 (Solid Earth dynamics, hazards and resources) and to IDL's FCT-projects FCT/UID/GEO/50019/2019-IDL and FCT/UIDB/50019/2020IDL. Detailed revision by J.B. Murphy greatly improved a first version of this manuscript.

\section{References}

Alcock, J. E., Martínez Catalán, J. R., Rubio Pascual, F. J., Díez Montes, A., Díez Fernández, R., Gómez Barreiro, J., Arenas, R., Dias da Silva, Í., and González-Clavijo, E.: 2-D thermal modeling of HT-LP metamorphism in NW and Central Iberia: Implications for Variscan magmatism, rheology of the lithosphere and orogenic evolution, Tectonophysics, 657, 21-37, doi: 10.1016/j.tecto.2015.05.022, 2015

Alonso, J. L.: Sequences of thrusts and displacement transfer in the superposed duplexes of the Esla Nappe Region (cantabrian zone, nw spain), Journal of Structural Geology, 9, 969-983, doi: https://doi.org/10.1016/0191$\underline{8141(87) 90005-8}, 1987$

Alonso, J. L. and Rodríguez Fernández, L. R.: Aportaciones al conocimiento de la estructura del Sinclinorio de Verin, Cuadernos Xeolóxicos de Laxe, 1981. 93-122, 1981

Alvarez-Marron, J.: Three-dimensional geometry and interference of fault-bend folds: examples from the Ponga Unit, Variscan Belt, NW Spain, Journal of Structural Geology, 17, 549-560, doi: https://doi.org/10.1016/01918141(94)00075-B, 1995 
Álvaro, J. J., Casas, J. M., Clausen, S., and Quesada, C.: Early Palaeozoic geodynamics in NW Gondwana, Journal of Iberian Geology, 44, 551-565, doi: 10.1007/s41513-018-0079-x, 2018

Aller, J., Bastida, F., Brime, C., and Perez-Estaun, A.: Cleavage and its relation with metamorphic grade in the Cantabrian Zone (Hercynian of North-West Spain), Sciences Géologiques, bulletins et mémoires, 255-272, doi: 10.3406/sgeol.1987.1765, 1987

Aller, J., Valín, M. a. L., García-López, S., Brime, C., and Bastida, F.: Superposition of tectono-thermal episodes in the southern Cantabrian Zone (foreland thrust and fold belt of the Iberian Variscides, NW Spain), Bulletin de la Société Géologique de France, 176, 487-497, doi: 10.2113/176.6.487, 2005 Arboleya, M. L.: La estructura del Manto del Esla (Cordillera Cantábrica, León), Boletin geologico y minero, 1981. 19-40, 1981

Arenas, R. and Martínez Catalán, J. R.: Low-P metamorphism following a Barrovian-type evolution. Complex tectonic controls for a common transition, as deduced in the Mondoñedo thrust sheet (NW Iberian Massif), Tectonophisics, 365, 143-164, doi: 10.1016/S0040-1951(03)00020-9, 2003

Arenas, R. and Sanchez-Martinez, S.: Variscan ophiolites in NW Iberia: Tracking lost Paleozoic oceans and the assembly of Pangea, Episodes, 38, 315-333, doi: 10.18814/epiiugs/2015/v38i4/82427, 2015

Azor, A., Dias da Silva, Í., Gómez Barreiro, J., González-Clavijo, E., Martínez Catalán, J. R., Simancas, J. F., Martínez Poyatos, D., Pérez-Cáceres, I., González Lodeiro, F., Expósito, I., Casas, J. M., Clariana, P., GarcíaSansegundo, J., and Margalef, A.: Deformation and Structure. In: The Geology of Iberia: A Geodynamic Approach: Volume 2: The Variscan Cycle, Quesada, C. and Oliveira, J. T. (Eds.), Springer International Publishing, Cham, doi: 10.1007/978-3-030-10519-8 10, 2019

Azor, A., Lodeiro, F. G., and Simancas, J. F.: Tectonic evolution of the boundary between the Central Iberian and Ossa-Morena zones (Variscan belt, southwest Spain), Tectonics, 13, 45-61, doi: 10.1029/93TC02724, 1994

Barnett-Moore, N., Hosseinpour, M., and Maus, S.: Assessing discrepancies between previous plate kinematic models of Mesozoic Iberia and their constraints, Tectonics, 35, 1843-1862, doi: 10.1002/2015TC004019, 2016

Bastida, F., Brime, C., García-López, S., and Sarmiento, G. N.: Tectono-thermal evolution in a region with thinskinned tectonics: the western nappes in the Cantabrian Zone (Variscan belt of NW Spain), International Journal of Earth Sciences, 88, 38-48, doi: 10.1007/s005310050244, 1999

Bastida, F. and Castro, S.: Estructura del sector septentrional de la Escama de Tamiza (Zona Cantábrica, NW de España), Trabajos de geología, 17, 67-87, 1988

Bastida, F., Marcos, A., Pérez-Estaún, A., and Pulgar, J.: Geometría y evolución estructural del Manto de Somiedo (Zona Cantábrica, NO de España), Boletín Geológico y Minero, 95, 3-25, 1984

Braid, J. A., Murphy, J. B., Quesada, C., and Mortensen, J.: Tectonic escape of a crustal fragment during the closure of the Rheic Ocean: U-Pb detrital zircon data from the Late Palaeozoic Pulo do Lobo and South Portuguese zones, southern Iberia, Journal of the Geological Society, 383-392, doi: 10.1144/0016-76492010-104, 168, 2011

Brun, J. P. and Burg, J. P.: Combined thrusting and wrenching in the Ibero-Armorican arc: A corner effect during continental collision, Earth and Planetary Science Letters, 61, 319-332, 1982, doi: 10.1016/0012-821X(82)90063-2, 1982

Bulnes, M. and Aller, J.: Three-dimensional geometry of large-scale fault-propagation folds in the Cantabrian Zone, NW Iberian Peninsula, Journal of Structural Geology, 24, 827-846, doi: https://doi.org/10.1016/S01918141(01)00114-6, 2002 
Burg, J. P., Bale, P., Brun, J.-P., and Girardeau, J.: Stretching lineation and transport direction in the IberoArmorican arc during the siluro-devonian collision, Geodinamica Acta, 1, 71-87, doi: 10.1080/09853111.1987.11105126, 1987

Camargo Rocha, R., Ventura Araújo, A. A., Santos Borrego, J., and Fonseca, P. E.: Transected folds with opposite patterns in Terena Formation (Ossa Morena Zone, Portugal): anomalous structures resulting from sedimentary basin anisotropies, Geodinamica Acta, 22, 157-163, doi: 10.3166/ga.22.157-163, 2009

Casas, J. M., Álvaro, J. J., Clausen, S., Padel, M., Puddu, C., Sanz-López, J., Sánchez-García, T., Navidad, M., Castiñeiras, P., and Liesa, M.: Palaeozoic Basement of the Pyrenees. In: The Geology of Iberia: A Geodynamic Approach: Volume 2: The Variscan Cycle, Quesada, C. and Oliveira, J. T. (Eds.), Springer International Publishing, Cham, doi: 10.1007/978-3-030-10519-8_8, 2019

Casas, J. M. and Murphy, J. B.: Unfolding the arc: The use of pre-orogenic constraints to assess the evolution of the Variscan belt in Western Europe, Tectonophysics, 736, 47-61, doi: https://doi.org/10.1016/j.tecto.2018.04.012, 2018 Casas Sainz, A. M.: Oblique tectonic inversion and basement thrusting in the Cameros Massif (Northern Spain), Geodinamica Acta, 6, 202-216, doi: 10.1080/09853111.1993.11105248, 1993

Colmenar, J.: The arrival of brachiopods of the Nicolella Community to the Mediterranean margin of Gondwana during the Late Ordovician: Palaeogeographical and palaeoecological implications, Palaeogeography, Palaeoclimatology, Palaeoecology, 428, 12-20, doi: https://doi.org/10.1016/j.palaeo.2015.03.030, 2015

Dallmeyer, R. D., Martínez Catalán, J. R., Arenas, R., Gil Ibarguchi, J. I., Gutiérrez-Alonso, G., Farias, P., Bastida, F., and Aller, J.: Diachronous Variscan tectonothermal activity in the NW Iberia Massif: Evidence from 40Ar/39Ar dating of regional fabrics, Tectonophysics, 277, 307-337, doi: 10.1016/S0040-1951(97)00035-8, 1997

Dias da Silva, Í.: Geología de las Zonas Centro Ibérica y Galicia - Trás-os-Montes en la parte oriental del Complejo de Morais, Portugal/España, Instituto Universitario de Geología "Isidro Parga Pondal" - Área de Xeoloxía e Minería do Seminario de Estudos Galegos, Coruña, 2014.

Dias da Silva, Í., González Clavijo, E., Barba, P., Valladares, M. I., and Ugidos, J. M.: Geochemistry of Lower Palaeozoic shales. A case study in a sector of the Iberian Variscides. In: Ordovician of the World - 11th International Symposium on the Ordovician System, Gutiérrez Marco, J. C., Rábano, I., and García-Bellido, D. (Eds.), Instituto Geológico y Minero de España, Alcalá de Henares, 2011

Dias da Silva, Í., Jensen, S., and González Clavijo, E.: Trace fossils from the Desejosa Formation (Schist and Greywacke Complex, Douro Group, NE Portugal): new Cambrian age constraints, Geologica Acta, 12, 109-120, doi: 10.1344/105.000002080, 2014a

Dias da Silva, Í., Valverde-Vaquero, P., González-Clavijo, E., Díez-Montes, A., and Martínez Catalán, J. R.: Structural and stratigraphical significance of $\mathrm{U}-\mathrm{Pb}$ ages from the Mora and Saldanha volcanic complexes (NE Portugal, Iberian Variscides), Geological Society, London, Special Publications, 405, 115-135, doi: $10.1144 / \mathrm{sp} 405.3,2014 \mathrm{~b}$

Dias da Silva, Í., Linnemann, U., Hofmann, M., González-Clavijo, E., Díez-Montes, A., and Martínez Catalán, J. R.: Detrital zircon and tectonostratigraphy of the Parautochthon under the Morais Complex (NE Portugal): implications for the Variscan accretionary history of the Iberian Massif, Journal of the Geological Society, 172, 45-61, doi: 10.1144 /jgs2014-005, 2015

Dias da Silva, Í., Díez Fernández, R., Díez-Montes, A., González Clavijo, E., and Foster, D. A.: Magmatic evolution in the N-Gondwana margin related to the opening of the Rheic Ocean-evidence from the Upper Parautochthon of the Galicia-Trás-os-Montes Zone and from the Central Iberian Zone (NW Iberian Massif), International Journal of Earth Sciences, 105, 1127-1151, doi: 10.1007/s00531-015-1232-9, 2016 
Dias da Silva, Í., Pereira, M. F., Silva, J. B., and Gama, C.: Time-space distribution of silicic plutonism in a gneiss dome of the Iberian Variscan Belt: The Évora Massif (Ossa-Morena Zone, Portugal), Tectonophysics, 747-748, 298317, doi: 10.1016/j.tecto.2018.10.015, 2018

Dias da Silva, Í., González Clavijo, E., and Díez-Montes, A.: The collapse of the Variscan belt: a Variscan lateral extrusion thin-skinned structure in NW Iberia, International Geology Review, 1-37, doi: 10.1080/00206814.2020.1719544, 2020

Dias, R. and Ribeiro, A.: The Ibero-Armorican Arc: A collision effect against an irregular continent?, Tectonophisics, 246, 113-128, doi: 10.1016/0040-1951(94)00253-6, 1995

Díez Fernández, R. and Pereira, M. F.: Strike-slip shear zones of the Iberian Massif: Are they coeval?, Lithosphere, 9, 726-744, doi: 10.1130/L648.1, 2017

Díez Fernández, R., Martínez Catalán, J. R., Arenas Martín, R., and Abati Gómez, J.: Tectonic evolution of a continental subduction-exhumation channel: Variscan structure of the basal allochthonous units in NW Spain, Tectonics, 30, 1-22, doi: 10.1029/2010TC002850, 2011

Díez Fernández, R., Parra, L. M. M., and Rubio Pascual, F. J.: Extensional flow produces recumbent folds in synorogenic granitoids (Padrón migmatitic dome, NW Iberian Massif), Tectonophysics, 703-704, 69-84, doi: 10.1016/j.tecto.2017.03.010, 2017

Díez Fernández, R. and Pereira, M. F.: Extensional orogenic collapse captured by strike-slip tectonics: Constraints from structural geology and $\mathrm{UPb}$ geochronology of the Pinhel shear zone (Variscan orogen, Iberian Massif), Tectonophysics, 691, 290-310, doi: 10.1016/j.tecto.2016.10.023, 2016

Escuder Viruete, J., Arenas, R., and Martínez Catalán, J. R.: Tectonothermal evolution associated with Variscan crustal extension, in the Tormes Gneiss dome (NW Salamanca, Iberian Massif, Spain), Tectonophysics, 238, 1-22, doi: 10.1016/0040-1951(94)90052-3, 1994

Farias, P., Gallastegui, G., González-Lodeiro, F., Marquínez, J., Martín Parra, L. M., Martínez Catalán, J. R., de Pablo Maciá, J. G., and Rodríguez Fernández, L. R.: Aportaciones al conocimiento de la litoestratigrafía y estructura de Galicia Central, Memórias da Faculdade de Ciências da Universidade do Porto, 1, 411-431, 1987

Fernández-Lozano, J., Pastor-Galán, D., Gutiérrez-Alonso, G., and Franco, P.: New kinematic constraints on the Cantabrian orocline: A paleomagnetic study from the Peñalba and Truchas synclines, NW Spain, Tectonophysics, 681, 195-208, doi: https://doi.org/10.1016/j.tecto.2016.02.019, 2016

García-López, S., Voldman, G. G., Bastida, F., and Aller, J.: Tectonothermal analysis of a major unit of the Cantabrian Zone: the Ponga unit (Variscan belt, NW Spain), International Journal of Earth Sciences, 107, 2727 2740, doi: 10.1007/s00531-018-1623-9, 2018

Gómez Barreiro, J., Martínez Catalán, J. R., Arenas, R., Castiñeiras, P., Abati, J., Díaz García, F., and Wijbrans, J. R.: Tectonic evolution of the upper allochtonon of the Órdenes complex (Northwestern Iberian Massif): Structural constraints to a poligenic peri-Gondwanan terrane, Geologic Society of America - Special paper, 423, 315-332, doi: $10.1130 / 2007.2423(15), 2007$

González Clavijo, E., Díez Balda, M. A., and Álvarez, F.: Structural study of a semiductile strike-slip system in the Central Iberian Zone (Variscan Fold Belt, Spain): Structural controls on gold deposits, Geologische Rundschau, 82, 448-460, doi: 10.1007/BF00212409, 1993

González Clavijo, E., Dias da Silva, Í. F., Gutiérrez-Alonso, G., and Díez Montes, A.: U/Pb age of a large dacitic block locked in an Early Carboniferous synorogenic mélange in the Parautochthon of NW Iberia: New insights on the structure/sedimentation Variscan interplay, Tectonophysics, 681, 159-169, doi: 10.1016/j.tecto.2016.01.001, 2016 
Guimerà, J.: Structure of an intraplate fold-and-thrust belt: The Iberian Chain. A synthesis, Geologica acta, 16, 0427-0438, doi: 10.1344/GeologicaActa2018.16.4.6., 2018

Guimerà, J., Alonso, Á., and Mas, J. R.: Inversion of an extensional-ramp basin by a newly formed thrust: the Cameros basin (N. Spain), Geological Society, London, Special Publications, 88, 433, doi: 10.1144/GSL.SP.1995.088.01.23, 1995

Guimerà, J., Mas, R., and Alonso, A.: Intraplate deformation in the NW Iberian Chain: Mesozoic extension and Tertiary contractional inversion, Journal of the Geological Society, 161, 291-303, doi: 10.1144/0016-764903-055, 2004

Gutiérrez-Alonso, G., Fernández-Suárez, J., and Weil, A. B.: Orocline triggered litospheric delamination, Geologic Society of America - Special paper, 383, 121-130, doi: 10.1130/0-8137-2383-3(2004) 383[121:OTLD] 2.0.CO;2, 2004

Gutiérrez-Alonso, G., Fernández-Suárez, J., Jeffries, T. E., Johnston, S. T., Pastor-Galán, D., Murphy, J. B., Franco, P., and Gonzalo, J. C.: Diachronous post-orogenic magmatism within a developping orocline in Iberia, European Variscides, Tectonics, 30, 17, doi: 10.1029/2010TC002845, 2011

Gutiérrez-Alonso, G., Johnston, S., Weil, A., Pastor-Galán, D., and Fernández-Suárez, J.: Buckling an orogen: the Cantabrian Orocline, GSA Today, 22, 4-9, doi: 10.1130/GSATG141A.1, 2012

Gutiérrez-Alonso, G., Collins, A. S., Fernández-Suárez, J., Pastor-Galán, D., González-Clavijo, E., Jourdan, F., Weil, A. B., and Johnston, S. T.: Dating of lithospheric buckling: 40Ar/39Ar ages of syn-orocline strike-slip shear zones in northwestern Iberia, Tectonophysics, 643, 44-54, doi: 10.1016/j.tecto.2014.12.009, 2015

Gutiérrez-Marco, J. C., San José, M. A., and Pieren, A. P.: Post-Cambrian Paleozoic stratigraphy. In: Pre-Mesozoic Geology of Iberia, Dallmeyer, R. D. and Martínez García, E. (Eds.), Springer-Verlag, Germany, 1990

Gutiérrez-Marco, J. C., Piçarra, J. M., Meireles, C. A., Cózar, P., García-Bellido, D. C., Pereira, Z., Vaz, N., Pereira, S., Lopes, G., Oliveira, J. T., Quesada, C., Zamora, S., Esteve, J., Colmenar, J., Bernárdez, E., Coronado, I., Lorenzo, S., Sá, A. A., Dias da Silva, Í., González-Clavijo, E., Díez-Montes, A., and Gómez-Barreiro, J.: Early Ordovician-Devonian Passive Margin Stage in the Gondwanan Units of the Iberian Massif. In: The Geology of Iberia: A Geodynamic Approach: Volume 2: The Variscan Cycle, Quesada, C. and Oliveira, J. T. (Eds.), Springer International Publishing, Cham, doi: 10.1007/978-3-030-10519-8_3, 2019

Jammes, S., Manatschal, G., Lavier, L., and Masini, E.: Tectonosedimentary evolution related to extreme crustal thinning ahead of a propagating ocean: Example of the western Pyrenees, Tectonics, 28, doi: 10.1029/2008TC002406, 2009

Julivert, M.: Decollement tectonics in the Hercynian Cordillera of Northwest Spain, American Journal of Science, 270, 1-29, doi: 10.2475/ajs.270.1.1, 1971

Julivert, M., Fonboté, J. M., Ribeiro, A., and Conde, L.: Memoria explicativa del Mapa Tectónico de la Península Ibérica y Baleares. Escala 1:1.000.000, Instituto Geológico y Minero de España, Madrid, 1972.

Julivert, M. and Marcos, A.: Superimposed folding under flexural conditions in the Cantabrian Zone (Hercynian Cordillera, northwest Spain), American Journal of Science, 273, 353-375, doi: 10.2475/ajs.273.5.353, 1973

Lefort, J. P.: Iberian-Armorican arc and Hercynian orogeny in western Europe, Geology, 7, 384-388, doi: 10.1130/0091-7613(1979)7<384:iaahoi >2.0.co;2, 1979

López-Plaza, M. and López-Moro, F. J.: El Domo del Tormes. In: Geología de España, Vera, J. A. (Ed.), SGEIGME, Madrid, 2004

Lotze, F.: Observaciones respecto de la división de los Varíscides de la Meseta Ibérica, Publ. Extr. Geol. España, V (1950), 145-167, 1945 
602

603

604

605

606

607

608

I.G.M.E.: Mapa geológico de España, 1:50 000. No 101 (Villablino). Servicio de Publicaciones del Ministerio de $\begin{array}{lllll}\text { Industria } & \mathrm{y} & \text { Energía, } & \text { Madrid, }\end{array}$ (http://info.igme.es/cartografiadigital/geologica/Magna50Hoja.aspx?intranet=false\&id=101), 1982 I.G.M.E.: Mapa geológico de España, 1:50 000. No 129 (La Robla). Servicio de Publicaciones del Ministerio de $\begin{array}{lllll}\text { Industria } & \text { y } & \text { Energía, } & \text { Madrid, } & \text { Mem. }\end{array}$ (http://info.igme.es/cartografiadigital/geologica/Magna50Hoja.aspx?intranet=false\&id=129), 1984 Marcos, A., Martínez Catalán, J. R., Gutiérrez Marco, J. C., and Pérez-Estaún, A.: Estratigrafía y paleogeografía. In: Geología de España, Vera, J. A. (Ed.), SGE-IGME, Madrid, 2004

Marcos, A. and Pulgar, J.: An approach to the tectonostratigraphic evolution of the Cantabrian foreland thrust and fold belt, Hercynian Cordillera of NW Spain, Neues Jahrbuch fuer Geologie und Palaeontologie. Abhandlungen, 163, 256-260, 1982

Marín, J., Pulgar, J., and Alonso, J.: La deformación alpina en el Domo de Valsurvio (Zona Cantábrica, NO de España), Revista de la Sociedad Geológica de España, 8, 111-116, 1995

Marquínez, J.: Mapa geológico de la Región del Cuera y los Picos de Europa, Trabajos de Geología, 18, 137-144, 1989

Marshak, S.: Salients, recesses, arcs, Oroclines, and Syntaxes - A review of ideas concerning the formation of mapview curves in fold-thrust belts, AAPG Memoir, 82, 131-144, 2004

Martínez Catalán, J. R.: Are the oroclines of the Variscan belt related to late Variscan strike-slip tectonics?, Terra Nova, 23, 241-247, doi: 10.1111/j.1365-3121.2011.01005.x, 2011

Martínez Catalán, J. R.: The Central Iberian arc, an orocline centered in the Iberian Massif and some implications for the Variscan belt, International Journal of Earth Sciences, 101, 1299-1314, doi: 10.1007/s00531-011-0715-6, 2012

Martínez Catalán, J. R., Hacar Rodriguez, M. P., Villar Alonso, P., Perez-Estaún, A., and Gonzalez Lodeiro, F.: Lower Paleozoic extensional tectonics in the limit between the West Asturian-Leonese and Central Iberian Zones of the Variscan Fold-Belt in NW Spain, Geologische Rundschau, 81, 545-560, doi: 10.1007/bf01828614, 1992

Martínez Catalán, J. R., Arenas, R., and Díez Balda, M. A.: Large extensional structures developed during the emplacement of a crystalline thrust sheet: the Mondoñedo nappe (NW Spain), Journal of Structural Geology, 25, 1815-1839, doi: 10.1016/S0191-8141(03)00038-5, 2003

Martínez Catalán, J. R., Arenas, R., Díaz García, F., González Cuadra, P., Gómez Barreiro, J., Abati, J., Castiñeiras, P., Fernández-Suárez, J., Sánchez Martínez, S., Andonaegui, P., González Clavijo, E., Díez Montes, A., Rubio Pascual, F., and Valle Aguado, B.: Space and time in the tectonic evolution of the northwestern Iberian Massif: Implications for the Variscan belt. In: 4-D Framework of Continental Crust, Hatcher Jr., R. D., Carlson, M. P., McBride, J. H., and Martínez Catalán, J. R. (Eds.), Geologic Society of America, Boulder, doi: 10.1130/2007.1200(21), 2007

Martínez Catalán, J. R., Arenas, R., Abati, J., Sánchez Martínez, S., Díaz García, F., Fernández-Suárez, J., González Cuadra, P., Castiñeiras, P., Gómez Barreiro, J., Díez Montes, A., González Clavijo, E., Rubio Pascual, F., Andonaegui, P., Jeffries, T. E., Alcock, J. E., Díez Fernández, R., and López Carmona, A.: A rootless suture and the loss of the roots of a mountain chain: The Variscan Belt of NW Iberia, C.R. Geoscience, 341, 114-126, doi: 10.1016/j.crte.2008.11.004, 2009

Martínez Catalán, J. R., Rubio Pascual, F. J., Montes, A. D., Fernández, R. D., Barreiro, J. G., Dias Da Silva, Í., Clavijo, E. G., Ayarza, P., and Alcock, J. E.: The late Variscan HT/LP metamorphic event in NW and Central 
643

644

645

Iberia: relationships to crustal thickening, extension, orocline development and crustal evolution, Geological Society, London, Special Publications, 405, 225-247, doi: 10.1144/sp405.1, 2014

Martínez Catalán, J. R., González Clavijo, E., Meireles, C., Díez Fernández, R., and Bevis, J.: Relationships between syn-orogenic sedimentation and nappe emplacement in the hinterland of the Variscan belt in NW Iberia deduced from detrital zircons, Geological Magazine, 153, 38-60, doi: 10.1017/S001675681500028X, 2016 Martínez Catalán, J. R., Gómez Barreiro, J., Dias da Silva, Í., Chichorro, M., López-Carmona, A., Castiñeiras, P., Abati, J., Andonaegui, P., Fernández-Suárez, J., González Cuadra, P., and Benítez-Pérez, J. M.: Variscan Suture Zone and Suspect Terranes in the NW Iberian Massif: Allochthonous Complexes of the Galicia-Trás os Montes Zone (NW Iberia). In: The Geology of Iberia: A Geodynamic Approach: Volume 2: The Variscan Cycle, Quesada, C. and Oliveira, J. T. (Eds.), Springer International Publishing, Cham, doi: 10.1007/978-3-030-10519-8_4, 2019 Matte, P. and Ribeiro, A.: Forme et orientation de l'ellipsoide de deformation dans la vibration Hercynienne de Galicia: relation avec le plissement et hypotheses sur la genese de l'arc Iberio-Armoricain, Comptes Rendus de l'Academie des Sciences, 1975. 2825-2828, 1975

Merino-Tomé, O. A., Bahamonde, J. R., Colmenero, J. R., Heredia, N., Villa, E., and Farias, P.: Emplacement of the Cuera and Picos de Europa imbricate system at the core of the Iberian-Armorican arc (Cantabrian zone, north Spain): New precisions concerning the timing of arc closure, GSA Bulletin, 121, 729-751, doi: 10.1130/B26366.1, 2009

Merino-Tomé, O., Alonso, J. L., Bahamonde, J.R., Marcos, A., Colmenero, J.R., Villa, E., and Suárez, A.: Foreland Basin at the Cantabrian Zone: Evolution from the Distal Foreland Basin Successions to Wedge-Top Deposition and the Tightening of the Ibero-Armorican Arc. In: The Geology of Iberia: A Geodynamic Approach: Volume 2: The Variscan Cycle, Quesada, C. and Oliveira, J. T. (Eds.), Springer International Publishing, Cham, doi: 10.1007/9783-030-10519-8_10, 2019

Montero, P., Bea, F., González Lodeiro, F., Talavera, C., and Whitehouse, M. J.: Zircon ages of the metavolcanic rocks and metagranites of the Ollo de Sapo Domain in central Spain: implications for the Neoproterozoic to Early Palaeozoic evolution of Iberia, Geological Magazine, 144, 963-976, doi: 10.1017/S0016756807003858, 2007

Montero, P., Bea, F., Corretgé, L. G., Floor, P., and Whitehouse, M. J.: U-Pb ion microprobe dating and $\mathrm{Sr}$ and $\mathrm{Nd}$ isotope geology of the Galiñeiro Igneous Complex: A model for the peraluminous/peralkaline duality of the Cambro-Ordovician magmatism of Iberia, Lithos, 107, 227-238, doi: 10.1016/j.lithos.2008.10.009, 2009

Muñoz, J. A.: Alpine Orogeny: Deformation and Structure in the Northern Iberian Margin (Pyrenees s.1.). In: The Geology of Iberia: A Geodynamic Approach: Volume 3: The Alpine Cycle, Quesada, C. and Oliveira, J. T. (Eds.), Springer International Publishing, Cham, doi: 10.1007/978-3-030-11295-0_9, 2019

Murphy, J. B., Quesada, C., Gutiérrez-Alonso, G., Johnston, S. T., and Weil, A.: Reconciling competing models for the tectono-stratigraphic zonation of the Variscan orogen in Western Europe, Tectonophysics, 681, 209-219, doi: http://dx.doi.org/10.1016/j.tecto.2016.01.006, 2016

Oliveira, J. T., González-Clavijo, E., Alonso, J., Armendáriz, M., Bahamonde, J. R., Braid, J. A., Colmenero, J. R., Dias da Silva, Í., Fernandes, P., Fernández, L. P., Gabaldón, V., Jorge, R. S., Machado, G., Marcos, A., MerinoTomé, Ó., Moreira, N., Murphy, J. B., Pinto de Jesus, A., Quesada, C., Rodrigues, B., Rosales, I., Sanz-López, J., Suárez, A., Villa, E., Piçarra, J. M., and Pereira, Z.: Synorogenic Basins. In: The Geology of Iberia: A Geodynamic Approach: Volume 2: The Variscan Cycle, Quesada, C. and Oliveira, J. T. (Eds.), Springer International Publishing, Cham, doi: 10.1007/978-3-030-10519-8_11, 2019

Pastor-Galán, D., Gutiérrez-Alonso, G., and Weil, A. B.: Orocline timing through joint analysis: Insights from the Ibero-Armorican Arc, Tectonophysics, 507, 31-46, doi: 10.1016/j.tecto.2011.05.005, 2011 
Pastor-Galán, D., Gutiérrez-Alonso, G., Mulchrone, K. F., and Huerta, P.: Conical folding in the core of an orocline. A geometric analysis from the Cantabrian Arc (Variscan Belt of NW Iberia), Journal of Structural Geology, 39, 210 223, doi: https://doi.org/10.1016/j.jsg.2012.02.010, 2012a

Pastor-Galán, D., Gutiérrez-Alonso, G., Zulauf, G., and Zanella, F.: Analogue modeling of lithospheric-scale orocline buckling: Constraints on the evolution of the Iberian-Armorican Arc, GSA Bulletin, 124, 1293-1309, doi: 10.1130/B30640.1, 2012b

Pastor-Galán, D., Groenewegen, T., Brouwer, D., Krijgsman, W., and Dekkers, M. J.: One or two oroclines in the Variscan orogen of Iberia? Implications for Pangea amalgamation, Geology, 43, 527-530, doi: 10.1130/g36701.1, $2015 \mathrm{a}$

Pastor-Galán, D., Ursem, B., Meere, P. A., and Langereis, C.: Extending the Cantabrian Orocline to two continents (from Gondwana to Laurussia). Paleomagnetism from South Ireland, Earth and Planetary Science Letters, 432, 223 231, doi: 10.1016/j.eps1.2015.10.019, 2015b

Pastor-Galán, D., Dekkers, M. J., Gutiérrez-Alonso, G., Brouwer, D., Groenewegen, T., Krijgsman, W., FernándezLozano, J., Yenes, M., and Álvarez-Lobato, F.: Paleomagnetism of the Central Iberian curve's putative hinge: Too many oroclines in the Iberian Variscides, Gondwana Research, 39, 96-113, doi: 10.1016/j.gr.2016.06.016, 2016 Pastor-Galán, D., Gutiérrez-Alonso, G., Dekkers, M. J., and Langereis, C. G.: Paleomagnetism in Extremadura (Central Iberian zone, Spain) Paleozoic rocks: extensive remagnetizations and further constraints on the extent of the Cantabrian orocline, Journal of Iberian Geology, doi: 10.1007/s41513-017-0039-x, 2017

Pastor-Galán, D., Dias da Silva, Í. F., Groenewegen, T., and Krijgsman, W.: Tangled up in folds: tectonic significance of superimposed folding at the core of the Central Iberian curve (West Iberia), International Geology Review, 61, 240-255, doi: 10.1080/00206814.2017.1422443, 2019

Pereira, M. F., Chichorro, M., Silva, J. B., Ordóñez-Casado, B., Lee, J. K. W., and Williams, I. S.: Early carboniferous wrenching, exhumation of high-grade metamorphic rocks and basin instability in SW Iberia: Constraints derived from structural geology and $\mathrm{U}-\mathrm{Pb}$ and 40Ar-39Ar geochronology, Tectonophysics, 558-559, 28-44, doi: http://dx.doi.org/10.1016/j.tecto.2012.06.020, 2012

Pereira, M. F., Gama, C., Dias da Silva, Í., Fuenlabrada, J. M., Silva, J. B., and Medina, J.: Isotope geochemistry evidence for Laurussian-type sources of South-Portuguese Zone Carboniferous turbidites (Variscan orogeny), Geological Society, London, Special Publications, 503, SP503-2019-2163, doi: 10.1144/sp503-2019-163, 2020

Pérez-Cáceres, I., Martínez Poyatos, D., Simancas, J. F., and Azor, A.: Testing the Avalonian affinity of the South Portuguese Zone and the Neoproterozoic evolution of SW Iberia through detrital zircon populations, Gondwana Research, 42, 177-192, doi: https://doi.org/10.1016/j.gr.2016.10.010, 2017

Pérez-Estaún, A., Bastida, F., Alonso, J. L., Marquínez, J., Aller, J., Alvarez-Marrón, J., Marcos, A., and Pulgar, J. A.: A thin-skinned tectonics model for an arcuate fold and thrust belt: The Cantabrian Zone (Variscan IberoArmorican Arc), Tectonics, 7, 517-537, doi: 10.1029/TC007i003p00517, 1988

Pérez-Estaún, A., Bastida, F., Martínez Catalán, J. R., Gutierrez Marco, J. C., Marcos, A., and Pulgar, J. A.: West Asturian-Leonese Zone. Stratigraphy. In: Pre-Mesozoic Geology of Iberia, Dallmeyer, R. D. and Martínez García, E. (Eds.), Springer-Verlag, Berlin, 1990

Pulgar, J., Alonso, J., Espina, R., and Marín, J.: La deformación alpina en el basamento varisco de la Zona Cantábrica, Trabajos de geologia, 21, 283-295, 1999

Quesada, C.: Geological constraints on the Paleozoic tectonic evolution of tectonostratigraphic terranes in the Iberian Massif, Tectonophysics, 185, 225-245, doi: 10.1016/0040-1951(91)90446-Y, 1991 
Ribeiro, A. (Ed.): Contribution à l'étude téctonique de Trás-os-Montes Oriental, Serviços Geológicos de Portugal, Lisboa, 1974.

Ribeiro, A., Pereira, E., and Severo, L.: Análise da deformação da zona de cisalhamento Porto-Tomar na transversal de Oliveira de Azeméis, Comunicações dos Serviços Geológicos de Portugal, 66, 3-9, 1980

Ribeiro, A., Pereira, E., Dias, R., Gil Ibarguchi, J. I., and Arenas, R.: Allochthonous Sequences. In: Pre-Mesozoic Geology of Iberia, Dallmeyer, R. D. and Garcia, E. M. (Eds.), Springer Berlin Heidelberg, Berlin, Heidelberg, doi: 10.1007/978-3-642-83980-1_15, 1990

Robardet, M.: Alternative approach to the Variscan Belt in southwestern Europe: Preorogenic paleobiogeographical constraints. In: Variscan-Appalachian dynamics: The building of the late Paleozoic basement, Catalán, J. R. M., Hatcher, R. D., Jr., Arenas, R., and García, F. D. (Eds.), Geological Society of America, doi: 10.1130/0-8137-2364$7.1,2002$

Rodrigues, J. F., Ribeiro, A., and Pereira, E.: Complexo de Mantos Parautóctones do NE de Portugal:estructura interna e tectonoestratigrafia. In: Geologia de Portugal, Dias, R., Araújo, A., Terrinha, P., and Kullberg, J. C. (Eds.), Escolar Editora, Lisboa, 2013

Rubio Pascual, F. J., López-Carmona, A., and Arenas, R.: Thickening vs. extension in the Variscan belt: P-T modelling in the Central Iberian autochthon, Tectonophysics, 681, 144-158, doi: 10.1016/j.tecto.2016.02.033, 2016

Sánchez-García, T., Bellido, F., and Quesada, C.: Geodynamic setting and geochemical signatures of CambrianOrdovician rift-related igneous rocks (Ossa-Morena Zone, SW Iberia), Tectonophysics, 365, 233-255, doi: https://doi.org/10.1016/S0040-1951(03)00024-6, 2003

Sánchez-García, T., Chichorro, M., Solá, A. R., Álvaro, J. J., Díez-Montes, A., Bellido, F., Ribeiro, M. L., Quesada, C., Lopes, J. C., Dias da Silva, Í., González-Clavijo, E., Gómez Barreiro, J., and López-Carmona, A.: The Cambrian-Early Ordovician Rift Stage in the Gondwanan Units of the Iberian Massif. In: The Geology of Iberia: A Geodynamic Approach: Volume 2: The Variscan Cycle, Quesada, C. and Oliveira, J. T. (Eds.), Springer International Publishing, Cham, doi: 10.1007/978-3-030-10519-8_2, 2019

Shaw, J., Johnston, S. T., Gutiérrez-Alonso, G., and Weil, A. B.: Oroclines of the Variscan orogen of Iberia: Paleocurrent analysis and paleogeographic implications, Earth and Planetary Science Letters, 329-330, 60-70, doi: 10.1016/j.eps1.2012.02.014, 2012

Shaw, J., Gutiérrez-Alonso, G., Johnston, S. T., and Pastor Galán, D.: Provenance variability along the Early Ordovician north Gondwana margin: Paleogeographic and tectonic implications of U-Pb detrital zircon ages from the Armorican Quartzite of the Iberian Variscan belt, Geological Society of America Bulletin, doi: 10.1130/b30935.1, 2014

Shelley, D. and Bossière, G. r.: Megadisplacements and the Hercynian orogen of Gondwanan France and Iberia. In: Variscan-Appalachian dynamics: The building of the late Paleozoic basement, Catalán, J. R. M., Hatcher, R. D., Jr., Arenas, R., and García, F. D. (Eds.), Geological Society of America, doi: 10.1130/0-8137-2364-7.209, 2002 Simancas, J. F., Azor, A., Martínez-Poyatos, D., Tahiri, A., El Hadi, H., González-Lodeiro, F., Pérez-Estaún, A., and Carbonell, R.: Tectonic relationships of Southwest Iberia with the allochthons of Northwest Iberia and the Moroccan Variscides, Comptes Rendus Geoscience, 341, 103-113, doi: 10.1016/j.crte.2008.11.003, 2009 Srivastava, S. P., Sibuet, J. C., Cande, S., Roest, W. R., and Reid, I. D.: Magnetic evidence for slow seafloor spreading during the formation of the Newfoundland and Iberian margins, Earth and Planetary Science Letters, 182, 61-76, doi: 10.1016/S0012-821X(00)00231-4, 2000 
766

767
Valín, M. L., García-López, S., Brime, C., Bastida, F., and Aller, J.: Tectonothermal evolution in the core of an arcuate fold and thrust belt: the south-eastern sector of the Cantabrian Zone (Variscan belt, north-western Spain), Solid Earth, 7, 1003-1022, doi: 10.5194/se-7-1003-2016, 2016 Valverde-Vaquero, P., Cuesta, A., Gallastegui, G., Suárez, O., Corretgé, L., and Dunning, G.: U-Pb dating of late Variscan magmatism in the Cantabrian Zone (Northern Spain), Terra Abstracts, 101, 1999.

Vallenzuela, S., Alías, G., and Casas, J. M.: Superposition relations of microfabrics in the northern hanging-wall block of the Évora Massif (Ossa-Morena Zone), IX Congreso Geológico de España (Geotemas 16), Huelva, 109$112,2016$.

Warburton, J. and Alvarez, C.: A thrust tectonic interpretation of the Guadarrama Mountains, Spanish Central System. Libro homenaje a Rafael Soler, Asociación de Geólogos y Geofísicos Españoles del Petróleo, 1989 Weil, A. B., Van der Voo, R., van der Pluijm, B. A., and Parés, J. M.: The formation of an orocline by multiphase deformation: a paleomagnetic investigation of the Cantabria-Asturias Arc (northern Spain), Journal of Structural Geology, 22, 735-756, doi: 10.1016/S0191-8141(99)00188-1, 2000

Weil, A. B., Van der Voo, R., and Van der Plujim, B. A.: Oroclinal bending and evidence against the Pangea megashear: The Cantabria-Asturias arc (northern Spain), Geology, 29, 991-994, doi: 10.1130/00917613(2001)029<0991:OBAEAT>2.0.CO;2, 2001

Weil, A. B.: Kinematics of orocline tightening in the core of an arc: Paleomagnetic analysis of the Ponga Unit, Cantabrian Arc, northern Spain, Tectonics, 25, doi: 10.1029/2005tc001861, 2006

Weil, A. B., Gutiérrez-Alonso, G., and Conan, J.: New time constraints on lithospheric-scale oroclinal bending of the Ibero-Armorican Arc: a palaeomagnetic study of earliest Permian rocks from Iberia, Journal of the Geological Society, 167, 127-145, doi: 10.1144/0016-76492009-002, 2010

Weil, A. B., Gutiérrez-Alonso, G., Johnston, S. T., and Pastor-Galán, D.: Kinematic constraints on buckling a lithospheric-scale orocline along the northern margin of Gondwana: A geologic synthesis, Tectonophysics, 582, 2549, doi: 10.1016/j.tecto.2012.10.006, 2013a

Weil, A. B., Gutiérrez-Alonso, G., and Wicks, D.: Investigating the kinematics of local thrust sheet rotation in the limb of an orocline: a paleomagnetic and structural analysis of the Esla tectonic unit, Cantabrian-Asturian Arc, NW Iberia, International Journal of Earth Sciences, 102, 43-60, doi: 10.1007/s00531-012-0790-3, 2013b

Weil, A., Pastor-Galán, D., Johnston, S. T., and Gutiérrez-Alonso, G.: Late/Post Variscan Orocline Formation and Widespread Magmatism. In: The Geology of Iberia: A Geodynamic Approach: Volume 2: The Variscan Cycle, Quesada, C. and Oliveira, J. T. (Eds.), Springer International Publishing, Cham, doi: 10.1007/978-3-030-10519814,2019

Young, T. P.: The lithostratigraphy of the upper Ordovician of central Portugal, Journal of the Geological Society, 145, 377-392, doi: 10.1144/gsjgs.145.3.0377, 1988

Young, T. P.: Ordovician sedimentary facies and faunas of southwest Europe: palaeogeographic and tectonic implications, Geological Society, London, Memoirs, 12, 421, doi: 10.1144/GSL.MEM.1990.012.01.39, 1990 
802

\section{FIGURE CAPTIONS}

Fig. 1. Map of the Variscan belt of Western and Central Europe at post-Variscan times (ca. 295 Ma, Early Permian) with the location of the different areas and structures referred to in the text, after Martínez-Catalán (2011) modified. Abbreviations: B (Buçaco); BCSZ (Badajoz-Córdoba shear zone); C (Crozon); CO (Corsica); CIZ (Central Iberian Zone); CZ (Cantabrian Zone); ECM (External crystalline massif of the Alps); FMC (French Massif Central); GTMZ (Galicia Tras-Os-Montes Zone); JPSZ (Juzbado-Peñalba shear zone); LC (Lizard Complex); LLF (Layale-Lubine fault); LT (Leon terrane shear zone); MAD (Mid Armorican Domain); MDZ (Moldanubian Zone); MM (Maures Massif); MS (Moravo-Silesian Unit); NAD (North Armorican Domain); NASZ (North Armorican shear zone); NEF (Nort-sur Erdre fault); OMZ (Ossa Morena Zone); PY (Pyrenees); PTSZ (Porto-Tomar shear zone); RHZ (Rheno Hercynian Zone); SA (Sardinia); SAD (Southern Armorican Domain); SAF (Southern Armorican front); SASZ (South Armorican shear zone, N and S: northern and southern branches); SISZ (Southern Iberia shear zone); SPZ (South Portuguese Zone); SXZ (Saxo-Thuringian Zone); TBZ (Teplá-Barrandian Zone); VF (Variscan Front); VM (Vosgues Massif); WALZ (West Asturian Leonese Zone). See text for explanation.

Fig. 2. Various models for the formation of the Ibero-Armorican Arc. A) Indentor model after Sánchez-García et al. (2003). B) Oroclinal bending about a vertical axis after Pastor-Galán et al. (2017). C) Dextral mega-shear model from Martínez-Catalán et al. (2007). D) Combination of margin-controlled and buckling from Casas and Murphy (2018).

Fig. 3. Contraction related to $90^{\circ}$ rotations of both arms of an initially linear orogen with different initial lengths.

Fig. 4. Contraction related to: A) oroclinal bending about a vertical axis of an initial linear orogeny (after PastorGalán et al., 2017 modified); B) litospheric bending as a response to strike-slip faulting (after Martínez-Catalán et al., 2007 modified); C) arc formed as a result of combination of margin-controlled curve and buckling (after Casas and Murphy, 2018 modified).

Fig. 5. Estimation of the amount of lost lithosphere related to: A) oroclinal bending about a vertical axis of an initial linear orogeny (after Pastor-Galán et al., 2017 modified); B) litospheric bending as a response to strike-slip faulting (after Martínez-Catalán et al., 2007 modified); C) arc formed as a result of combination of margin-controlled curve and buckling (after Casas and Murphy, 2018 modified).

Fig. 6. A) Simplified geological map of the eastern rim of the Morais Allochthonous Complex (Galicia-Trás-osMontes Zone) and the underlying parautochthonous and autochthonous domains, showing the main Variscan structures and the location of the cross section in B. This area is located in the axial zone of the Central Iberian Arc (CIA). B) Cross section cutting the axial zone of the CIA showing the horizontal shortening related to the $\mathrm{D}_{3}$ structures in the autochthon of the CIZ, underlying the GTMZ. The contraction produced by $\mathrm{D}_{3}$ folds at the base of the Armorican Quartzite (red thick lines) is measured in two sectors. Modified after Dias da Silva (2014) and Dias da Silva et al. (2020). Abbreviations: BLPD - Basal Lower Parautochthon Detachment; MTMT - Main Trás-osMontes Thrust. For location, see Fig. 1.

Fig. 7. A) Geological map of the Ponga Unit that is at the core of the Cantabrian Zone arc, from Alvarez-Marrón (1995) (location in the inset). B) Axial traces of folds grouped into three sets frontal, corner, and lateral folds by Alvarez-Marrón (1995). The fault-bend folds have varied dimensions and orientations depending on the dimensions and orientations of the ramps and flats of the thrusts. Corner folds form oblique to the other two sets, at the intersection of lateral and frontal ramps. The interference and tectonic superposition of lateral and frontal thrust 
https://doi.org/10.5194/se-2020-126

Preprint. Discussion started: 21 August 2020

(c) Author(s) 2020. CC BY 4.0 License.

841 structures cause the plunge of fold axis (see Alvarez-Marron, 1995 for the classification of the different types of fold 842 interactions). Frontal folds plunges are in the direction perpendicular to the transport direction. Lateral folds over 843 frontal ramps plunges are in the direction of the tectonic transport. For location, see Fig. 1.

844 Fig. 8. A) Distribution of footwall ramps and flats in the Ponga Unit basal thrust is shown as an example of how

845

846

850 large folds such as Rio Color Antiform and Rio Monasterio Antiforms are related to the lateral footwall ramps of the basal thrust. Arrows indicate the emplacement direction of different thrust units mostly based on field kinematic indicators (Alvarez-Marrón, 1995).B) Geological cross-section that illustrated the geometries of large E-W folds, the thrust stacking and the lateral ramps in the footwall to the basal thrust (location in 7A). C) Block diagramme showing the ideal geometry of the basal thrust of the Ponga Unit (Alvarez-Marrón, 1995). For location, see Fig. 1.

Fig. 9. End-member plate models reconstructions of the Iberian Plate relative to a fixed Eurasia at chron M0. A) Taken from Srivastava et al. (2000); B) From Jammes et al. (2009), after Barnett-Moore et al. (2016) modified. Red lines: Variscan dextral strike-slip faults, blue lines: Variscan sinistral strike-slip faults. Latitudes, in degrees, refer to their present position in France. 
https://doi.org/10.5194/se-2020-126

Preprint. Discussion started: 21 August 2020

(c) Author(s) 2020. CC BY 4.0 License.

Solid Earth

Discussions

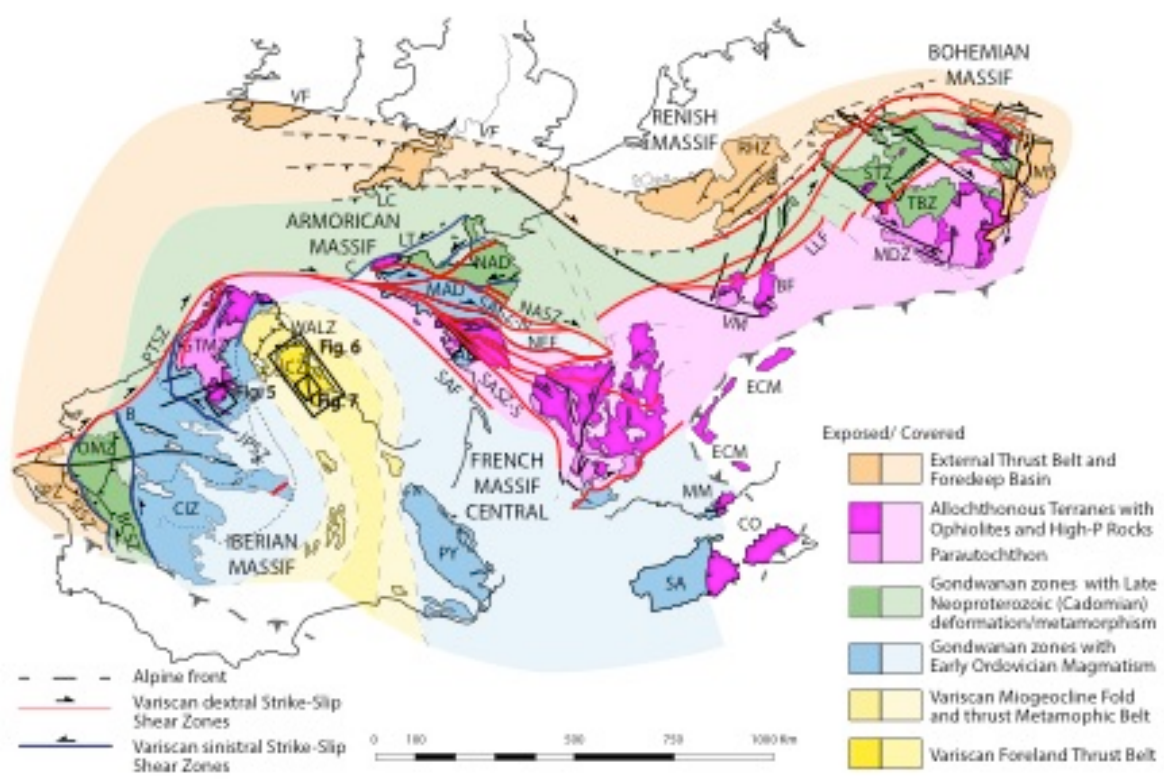

856

857

Fig. 1.

858 
https://doi.org/10.5194/se-2020-126

Preprint. Discussion started: 21 August 2020

(c) Author(s) 2020. CC BY 4.0 License.

(A)

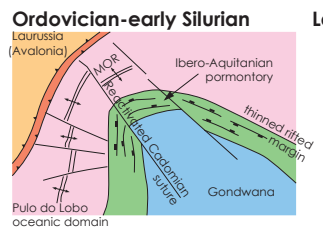

Late Devonian-early Visean

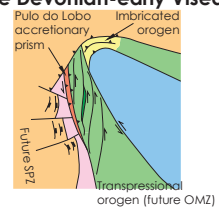

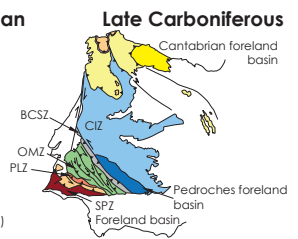

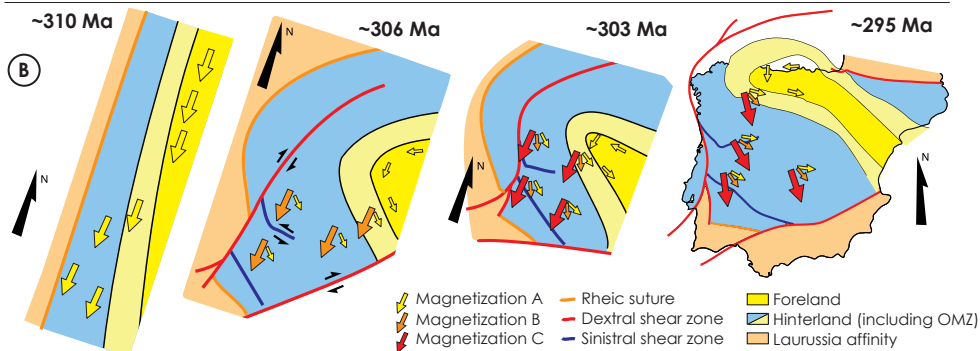

Magnetization B - Dextral shear zone $\square$ Hinterland (including OMZ

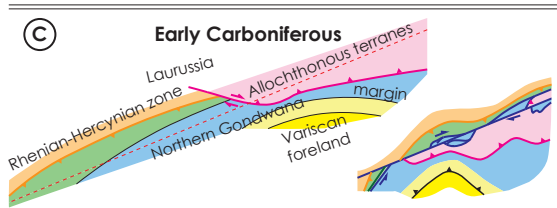

Uppermost Carboniferous

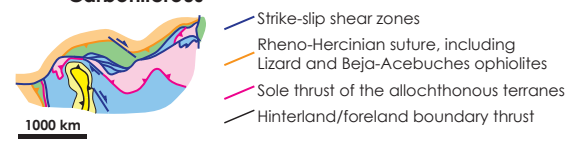

\section{$1000 \mathrm{~km}$}

(D) Before $360 \mathrm{Ma}$

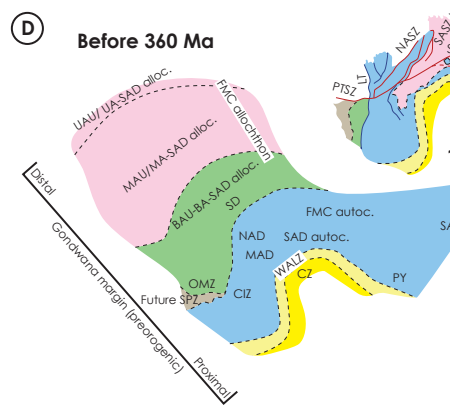

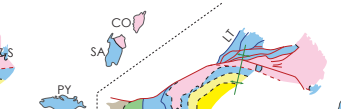

pry

$\sim 309 \mathrm{Ma}$

304-295 Ma

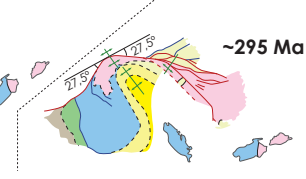

$\square$ External thrust belt and fordeep

$\square$ Allochthonous terranes, ophiolites and HP rocks

$\square$ Gondwana with Cadomian imprint

$\square$ Gondwana with Cambro-Ordovician

$\square$ Variscan Miogeocline fold and thrust

$\square$ Variscan foreland thrust belt

Fig. 2. 
https://doi.org/10.5194/se-2020-126

Preprint. Discussion started: 21 August 2020

(C) Author(s) 2020. CC BY 4.0 License.

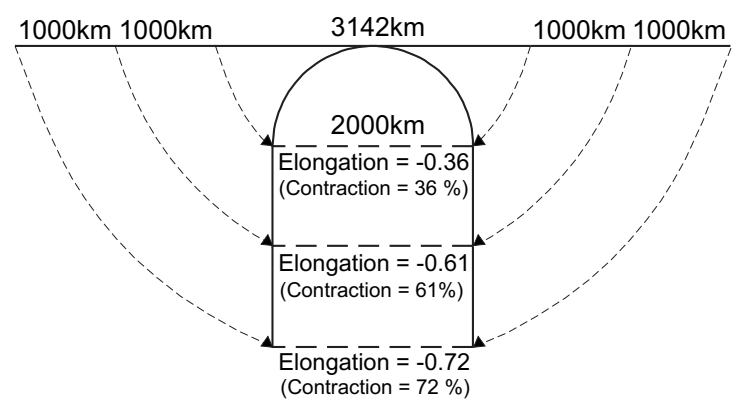

863

864

865

Fig. 3.

866 
https://doi.org/10.5194/se-2020-126

Preprint. Discussion started: 21 August 2020

(c) Author(s) 2020. CC BY 4.0 License.
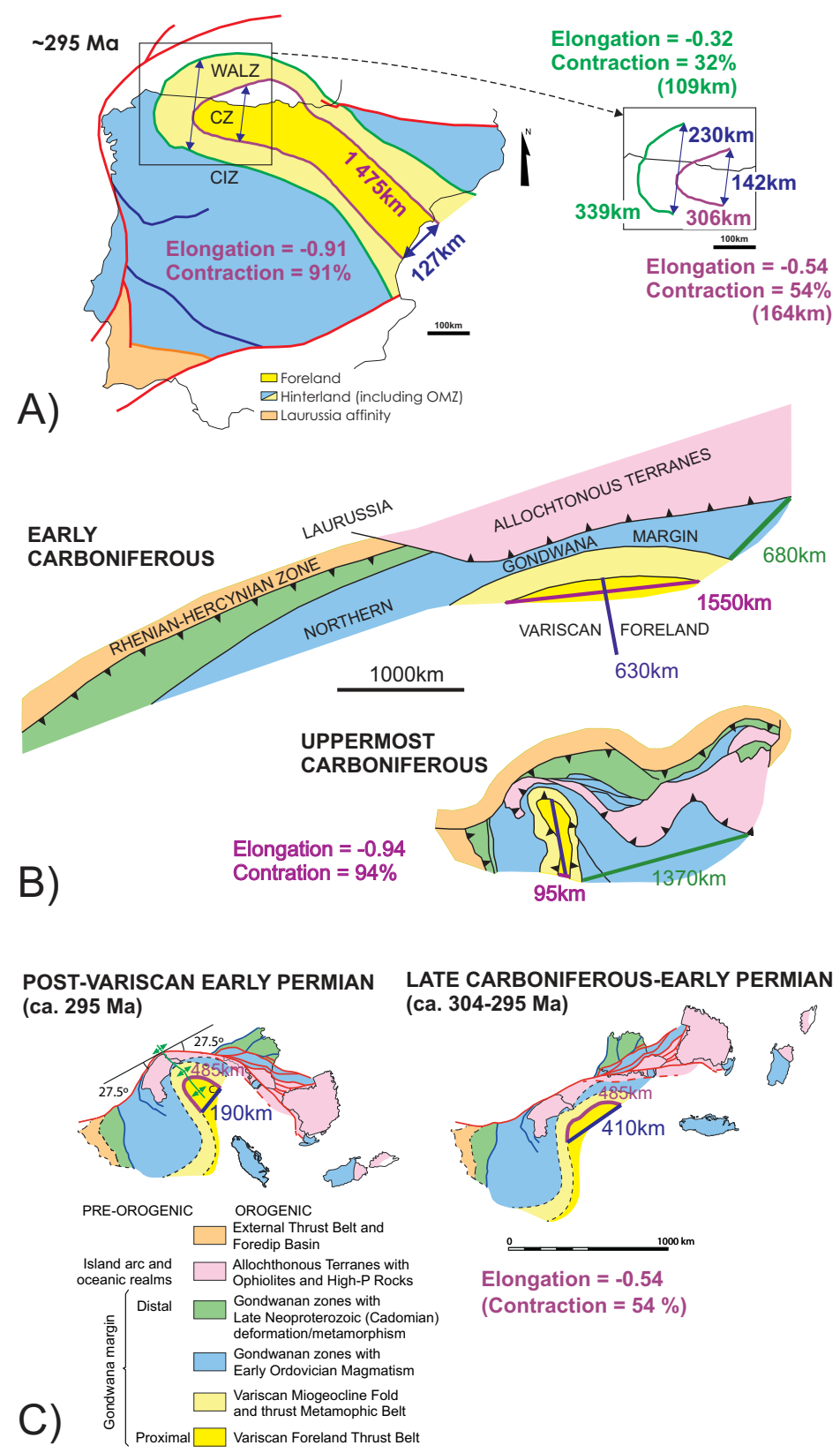

Fig. 4. 
https://doi.org/10.5194/se-2020-126

Preprint. Discussion started: 21 August 2020

(c) Author(s) 2020. CC BY 4.0 License.

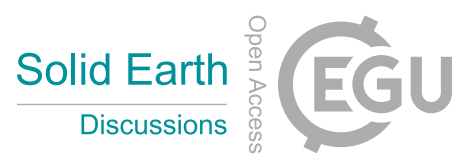

(c) (i)

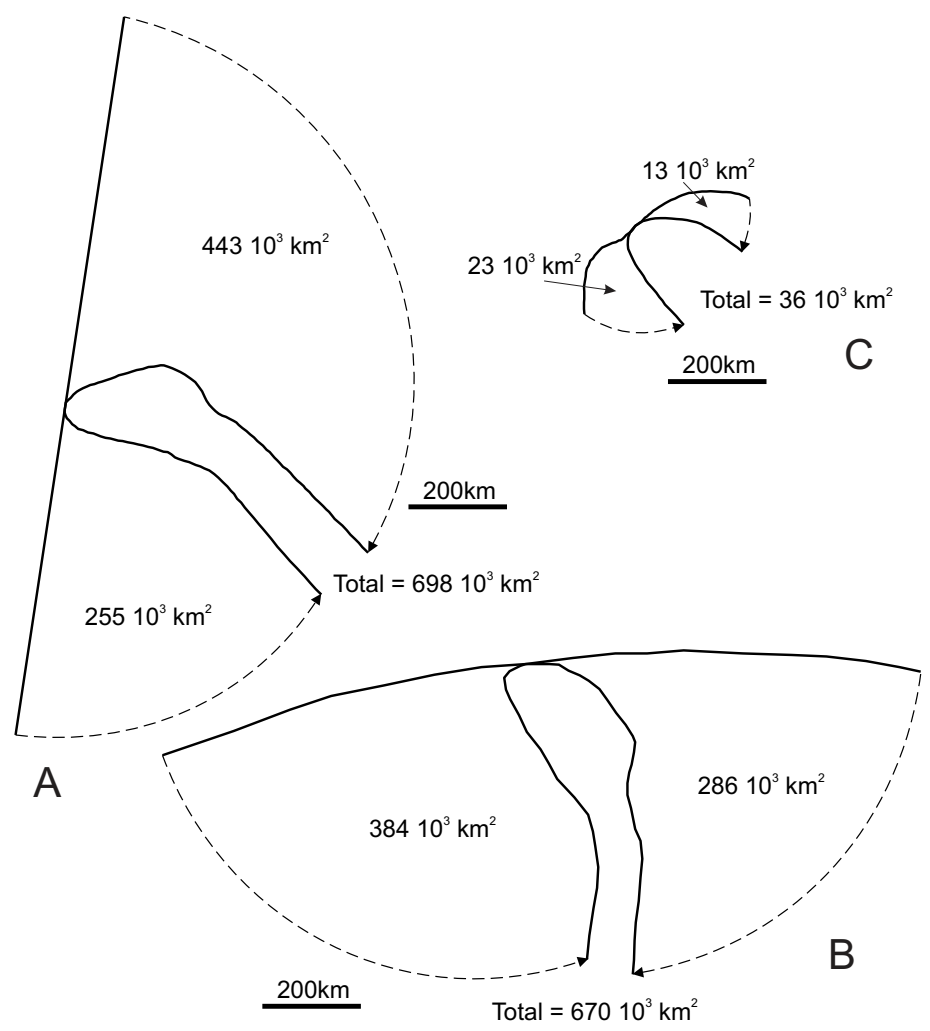

871

872

873

Fig. 5.

874 
https://doi.org/10.5194/se-2020-126

Preprint. Discussion started: 21 August 2020

(c) Author(s) 2020. CC BY 4.0 License.
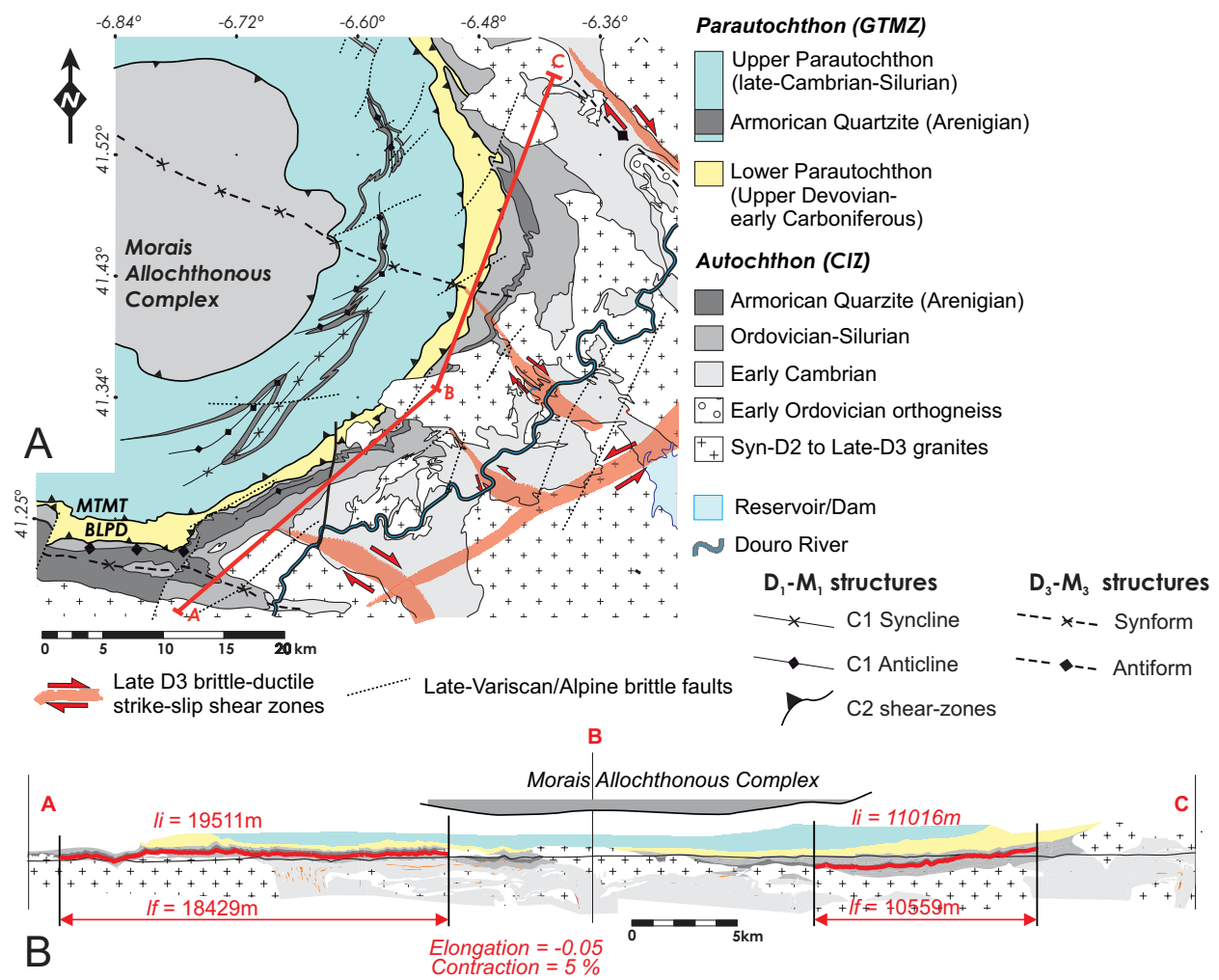

875

876

877

Fig. 6.

878 
https://doi.org/10.5194/se-2020-126

Preprint. Discussion started: 21 August 2020

(c) Author(s) 2020. CC BY 4.0 License.
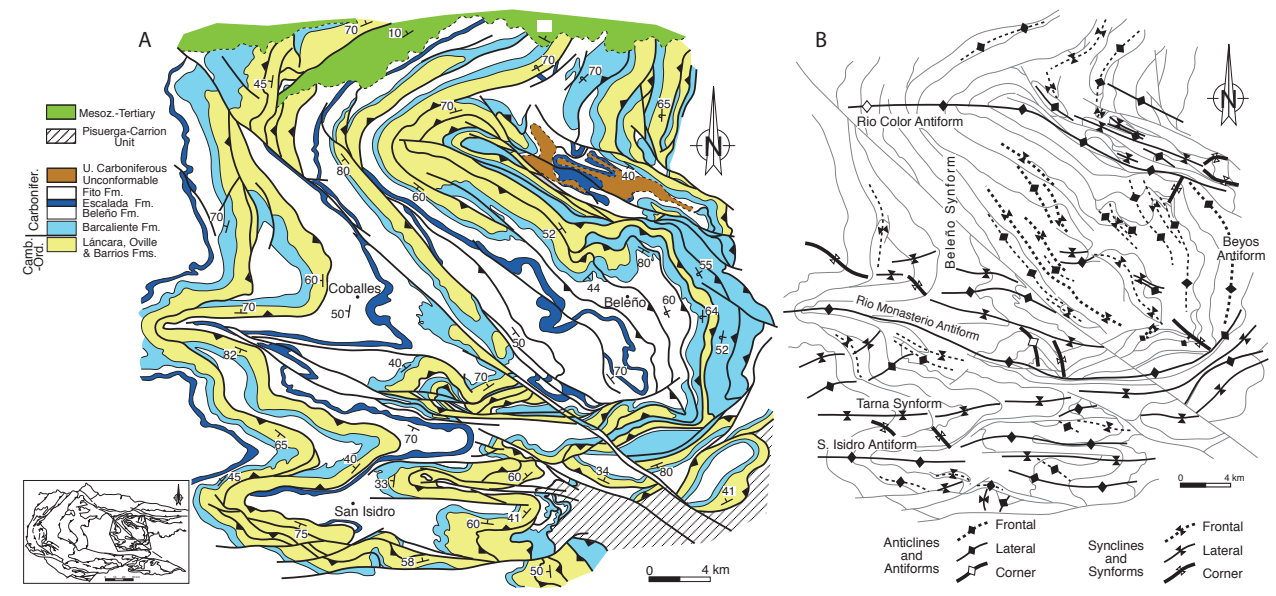

879

880

881

Fig. 7.

882 
https://doi.org/10.5194/se-2020-126

Preprint. Discussion started: 21 August 2020

(c) Author(s) 2020. CC BY 4.0 License.
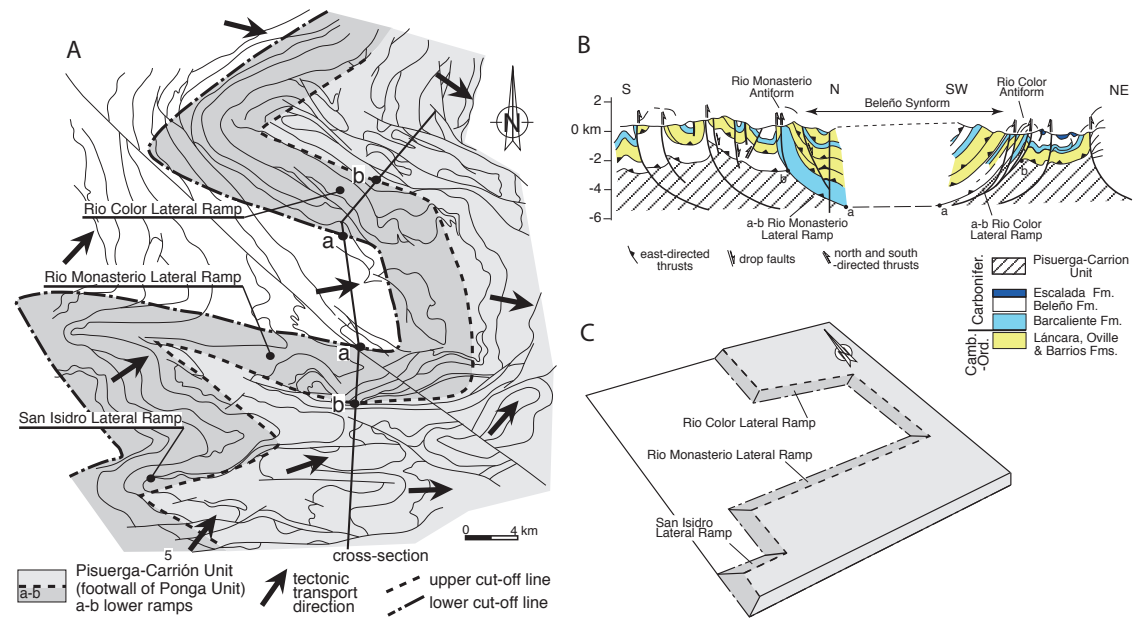

Fig. 8.

886 
https://doi.org/10.5194/se-2020-126

Preprint. Discussion started: 21 August 2020

(c) Author(s) 2020. CC BY 4.0 License.

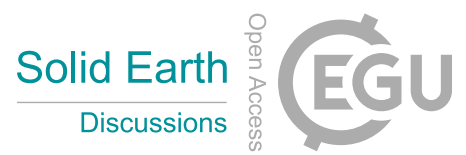

(c) (i)

A)

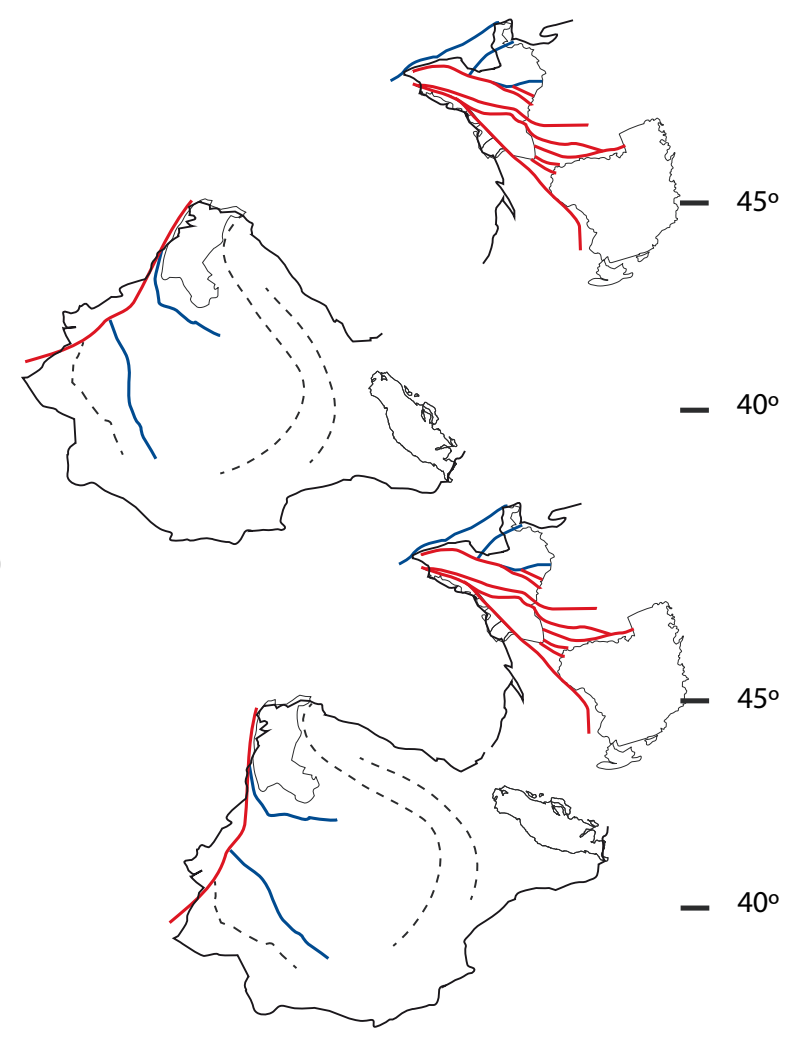

B)

887

888

889

Fig. 9.

890

891 